\title{
Evaluation of the Effect of a Number of Commercial Disinfectants on Pseudomonas aeruginosa Isolates Obtained from Human Infection Cases
}

\author{
Zohreh Hoseinpoor Mohammadabadi ${ }^{1 *}$, Azizollah Ebrahimi Kahrizsangi ${ }^{1}$, Azam Mokhtari ${ }^{1,2}$
}

1. Department of Pathobiology, Faculty of Veterinary Medicine, University of Shahrekord, Shahrekord, Iran

2. Zoonotic Disease Research Institute, Shahrekord University, Shahrekord, Iran

\section{ABSTRACT}

Background: Disinfectants have important clinical applications. Antibiotic resistance of some hospital pathogens such as Pseudomonas aeruginosa has led to the use of disinfectants. In the present study, the effects of four commercial disinfectants; Hydrocare, Benzalkonium Chloride, Cetrimide-C, and Vico sience on Pseudomonas aeruginosa isolates were investigated.

Materials \& Methods: The dilutions of four tested disinfectants recommended by the manufacturer were prepared and their effects on twelve Pseudomonas aeruginosa isolates were evaluated at five, ten, fifteen minutes after the bacterial inoculation.

Results \& Discussion: Hydrocare and Benzalkonium Chloride inhibited the growth of all strains while Cetrimide- $C$ disinfectant did not inhibit the growth of bacterial strains at any time. The Vico sience completely inhibited the growth of bacterial strains at ten and fifteen minutes after the addition of disinfectant. Since the recommended dilutions by the manufacturer were prepared and evaluated in the present study, the inefficiency of some of the disinfectants indicated that the evaluation and dilution assay of the disinfectant is necessary prior to routine use in laboratories or health centers.

Keywords: Disinfectant, Hydrocare, Benzalkonium Chloride, Vico sience, Cetrimide- C, Pseudomonas aeruginosa

Received: 2019/12/23; $\quad$ Accepted: 2020/05/4; Published Online: 2020/05/30

\begin{tabular}{|c|c|}
\hline Corresponding Information: & $\begin{array}{l}\text { Zohreh Hoseinpoor Mohammadabadi, Department of Pathobiology, Faculty of Veterinary Medicine, University of Shahrekord, } \\
\text { Shahrekord, Iran. Email: hoseinpoor325@gmail.com }\end{array}$ \\
\hline (c) (1) \$ & $\begin{array}{l}\text { This is an original open-access article distributed under the terms of the Creative Commons Attribution-noncommercial } 4.0 \text { International License which } \\
\text { edistribution of the material just in noncommercial usages with proper citation. }\end{array}$ \\
\hline
\end{tabular}

Use your device to scan and read the article online

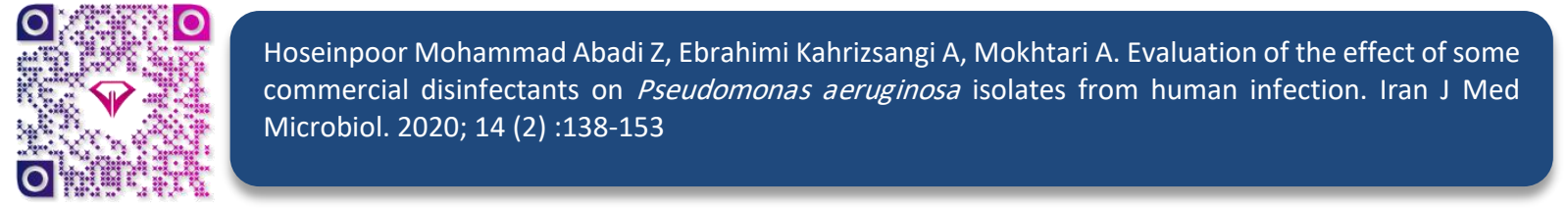

\section{Download citation: BibTeX | RIS | EndNote | Medlars | ProCite | Reference Manager | RefWorks} Send citation to: $\otimes_{\text {Mendeley }} \mathbf{z}$ Zotero ${ }_{\text {RefWorks }}$

\section{Introduction}

Nosocomial infections cause significant morbidity and mortality worldwide, and the pathogenic organisms that are responsible for such infections may resist antimicrobial agents. Therefore, understanding the activity of commercial disinfectants against environmental and pathogenic bacteria is very important (1) and the need for improved disinfection methods in therapeutic settings is abundantly felt (2). Pseudomonas aeruginosa is an important bacterium responsible for nosocomial infections (3) that may resistant to antibiotics (4). Therefore, it causes multidrug- resistance infections (5). Pseudomonas aeruginosa has a great importance due to its pathogenicity and adaptation to different environmental conditions (6). In addition, it is known to be an important human pathogen that can lead to nosocomial infections, especially in the intensive care unit, immune system disorder, wound infection, skin burn, eye infection, bacteremia, etc $(7,8)$. Which is a contaminant of medical instruments and causes of cross-infection in hospitals (9). Disinfection methods in hospitals are the main type of intervention against pathogenic microorganisms (10). Based on information reported by the European Center for Disease Prevention and Control (ECDC), About 33,000 people in Europe die each year from infections caused by multidrug-resistant bacteria (11). Eighty- eight 
thousand deaths from nosocomial infections have been reported in Iran in 1995 (12). In recent years, numerous studies have been conducted in different countries to evaluate the effect of disinfectants and antiseptics against bacterial agents (13). Until now various disinfectants and compositions have been developed by different companies, each has its own disadvantages and advantages. Since manufacturers often exaggerate their product descriptions, it is sometimes difficult to choose a suitable disinfectant. Incorrect use of disinfectants also exposes the bacteria to non-lethal concentrations of these solutions and can subsequently help develop resistance. Therefore, it is necessary to verify the accuracy of the dilution protocols provided by the manufacturing companies before applying their products $(13,14)$.

Given the aforementioned and the importance of Pseudomonas aeruginosa in the incidence and complication of nosocomial infections and its intrinsic resistance to antibiotics, the use of appropriate methods to control it is very important. Therefore, in the present study, the effect of four disinfectants: Hydrocare, Benzalkonium Chloride, Vico sience and Cetrimide- $\mathrm{C}$, with the dilutions recommended by the manufacturer in inhibiting the growth of Pseudomonas aeruginosa isolates obtained from human infections at different time intervals was investigated.

\section{Materials and Methods}

\section{Sample Collection}

For the present study, in May 2019, seven strains were collected from the laboratory of Alzahra Hospital in Isfahan and four isolates along with a standard strain were obtained from Microbial Bank Collection of Faculty of Veterinary Medicine, Shahrekord University.

\section{Verification of Bacterial Samples}

Bacterial samples were cultured on MacConkey agar medium and incubated at $37^{\circ} \mathrm{C}$ for $24-48 \mathrm{~h}$. To purify and isolate the proliferating bacteria, one to two similar colonies were cultured on sterile blood agar medium and incubated at $37^{\circ} \mathrm{C}$ for $24-48 \mathrm{~h}$ to achieve single and pure colonies.

To confirm the bacterial growth, the colonies were first morphologically and biochemically tested and then cultured in TSB medium and incubated at $37^{\circ} \mathrm{C}$ for 24 hours. After the incubation, the bacteria grown in TSB were re- cultured in blood agar medium. Smears were prepared from the colonies and catalase and oxidase tests were performed (15). Then a single colony was picked out and was cultured on MacConkey agar medium to grow lactose-negative colonies. The bacteria were then cultured on Cetrimide agar medium and the production of brown and green pigments was investigated (16). The colonies were then cultured in TSI medium to evaluate the bacterial ability to consume glucose, lactose, sucrose and also hydrogen sulfide gas production, alkaline reaction and not fermenting sugar (16). At a later stage, colonies were cultured in SIM medium to test for $\mathrm{SH} 2$ and indole production, and bacterial motility. Subsequently, colonies were cultured on Lithmus Milk medium to observe the color change and fragmented clots (15).

Evaluation of the Effect of Disinfectants on Pseudomonas aeruginosa Strains

Hydrocare is a very powerful detergent and disinfectant that is used to prevent infectious diseases caused by drinking water (17). According to the guidelines provided by Dominteb Company, Iran, a dilution of 4:100 Hydrocare disinfectants will be effective.

At first the stoke solution (4:100) of Hydrocare was prepared by adding $400 \mu \mathrm{L}$ of Hydrocare to $9.6 \mathrm{ml}$ of sterile distilled water. Then $1 \mathrm{ml}$ of the stock solution was added to $9 \mathrm{~mL}$ of Yeas Extract Broth medium.

Vico sience is a rapid eliminator of a wide range of pathogens (18). According to the guidelines provided by Sciene Laboratories (LS), a dilution of 1:100 Vico sience disinfectants will be effective. To prepare a stock solution (1: 10) of Vico sience, $1 \mathrm{~g}$ of disinfectant was dissolved 9 $\mathrm{ml}$ of sterile distilled water. Then $1 \mathrm{ml}$ of stock was dissolved in $9 \mathrm{ml}$ of Yeas Extract Broth medium.

Benzalkonium Chloride is a broad spectrum biocide (19) that has various applications in disinfection industry $(20,21)$, medicine (22) and home use (23). According to the guidelines provided by Benzalkonium Chloride (license number: D.T-140-93, Veterinary Organization), a dilution of 1:200 Benzalkonium Chloride disinfectants will be effective.

To prepare stock solution (1:200) of Benzalkonium Chloride $1 \mathrm{~mL}$ of disinfectant was dissolved in in $19 \mathrm{~mL}$ of sterile distilled water. Then, $1 \mathrm{~mL}$ of stock solution was added in $9 \mathrm{ml}$ of Yeas Extract Broth medium.

Cetrimide-C or Savlon is a widely used disinfectant that is applied for disinfection and bandage, rinsing and disinfecting hospital equipment and the operating room, etc. It is a strong bactericidal, safe and free of toxic effects (24). According to the guidelines provided by Cetrimide-C (license number: SH- 67- 013, Iran Daru Laboratory), a dilution of 1:200 Cetrimide-C disinfectants will be effective. For the preparation of Stoke solution (1:200) Cetrimide-C $1 \mathrm{~mL}$ of the disinfectant was dissolved in $19 \mathrm{ml}$ of sterile distilled water. Then, $1 \mathrm{~mL}$ of obtained stock solution was added in $9 \mathrm{~mL}$ of Yeas Extract Broth medium.

To investigate the effect of disinfectants on Pseudomonas aeruginosa isolates, 2-3 colonies were picked up from the purified culture of each strain and cultured in tubes containing TSB medium. After the incubation at $37^{\circ} \mathrm{C}$ for 24 hours, the turbidity of the tubes 
was compared with 0.5 McFarland standard turbidity $\left(2.5 \times 10^{8} \mathrm{CFU} / \mathrm{mL}\right)$. Whereas the turbidity of the tubes containing the bacterial strain was higher than the 0.5 McFarland standard, the $\mathrm{BHI}$ environment was added and if the absorbance of the bacterial strain was lower than the standard, the bacterial colony was added to achieve a concentration equal to the $0.5-\mathrm{McF}$ arland standard.

Subsequently, $100 \mu \mathrm{L}$ of the obtained 0.5-McFarland medium was added to $9.9 \mathrm{~mL}$ of TSB medium to give the concentration of strains at $2.5 \times 10^{6} \mathrm{CFU} / \mathrm{mL}$.

Then 100 microliter of bacterial strain at a concentration of $2.5 \times 10^{6} \mathrm{CFU} / \mathrm{mL}$ was added to tubes containing $9.9 \mathrm{~mL}$ of Yeas Extract Broth mixed with a disinfectant stock and it was completely mixed. At the times 5, 10, and 15 minutes after mixing the disinfectant dilution with the bacterial strain, $1 \mathrm{~mL}$ of the mixture of disinfectant and bacteria was added to 3 $\mathrm{mL}$ of $\mathrm{BHI}$ Broth and after a complete mixing, it was incubated at $37^{\circ} \mathrm{C}$ for 4 days. After this period of time, $50 \mu \mathrm{L}$ of the mixture of disinfectant and bacteria was seeded on a Nutrient agar medium and then it was incubated at $37^{\circ} \mathrm{C}$ for $24 \mathrm{~h}$. At the end, the growth or non-growth of bacterial colonies in was studied.

\section{Results and Discussion}

\section{Confirmation of Pseudomonas aeruginosa Isolates}

The results of biochemical tests performed for purified colonies has been shown in Figure 1.

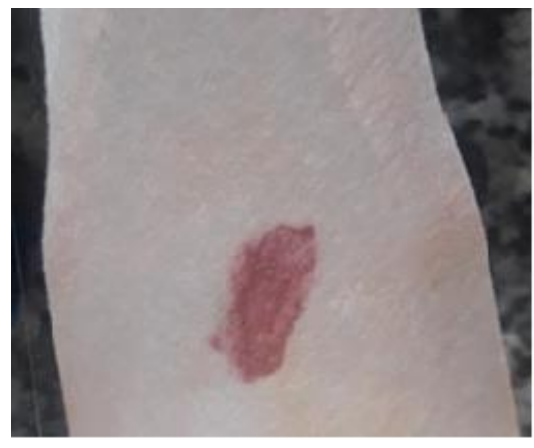

A

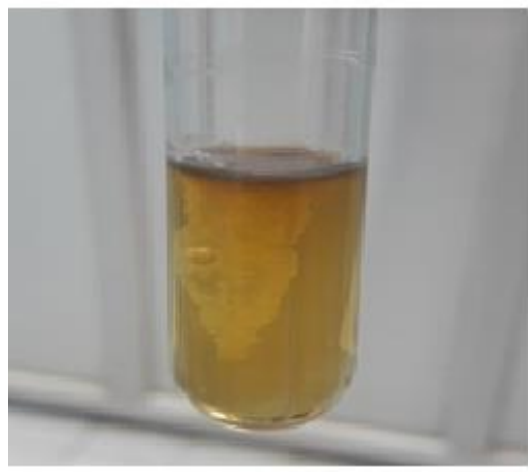

C

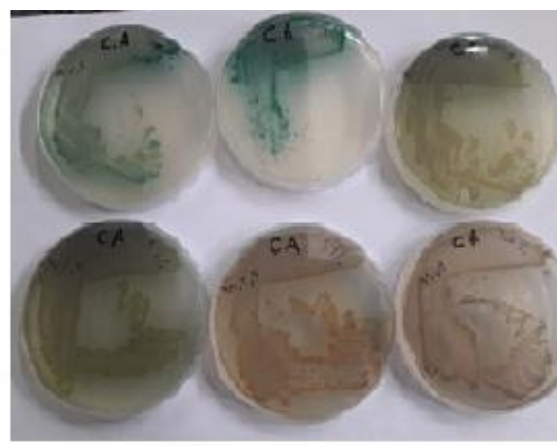

B

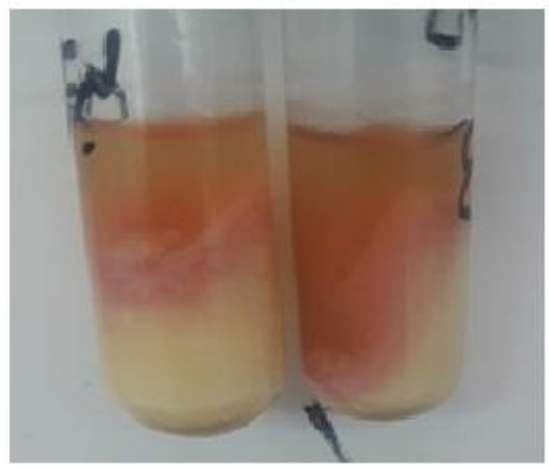

D

Figure 1. Confirmation of Pseudomonas aeruginosa isolates A: Oxidase test, the colony is dark purple and confirms Pseudomonas aeruginosa.

B: Cetrimide agar test, produces brown and green pigments and confirms Pseudomonas aeruginosa.

C: SIM test, inverted cedar view which is a sign of movement and confirmation of Pseudomonas aeruginosa.

D: Lithmus Milk test, the pink environment is white with patches and confirms Pseudomonas aeruginosa.

Investigating the Effect of Each of the Tested Disinfectants on Pseudomonas aeruginosa Isolates.

The results of this study to investigate the antimicrobial effect of four disinfectants, Hydrocare, Benzalkonium Chloride, Cetrimide-C and Vico science in eliminating Pseudomonas aeruginosa isolated from human infections in hospitals, in terms of whether the recommended concentration is in the instructions. Disinfectants affect the removal of Pseudomonas aeruginosa species in hospital centers, to what extent is the manufacturer's instructions correct and to what extent has it simply deviated from the introduction of products?

According to Table 1, in 5, 10 and 15 minutes no bacterial growth was observed in any of the isolates. 
In other words, the disinfectant Hydrocare kills the bacteria completely and has a $100 \%$ effect on the bacterium Pseudomonas aeruginosa.
According to Table 2, in 5, 10 and 15 minutes no bacterial growth was observed in any of the isolates. In other words, the disinfectant Benzalkonium Chloride kills the bacteria completely and has a $100 \%$ effect on the bacterium Pseudomonas aeruginosa.

Table 1. The effect of the disinfectant Hydrocare on Pseudomonas aeruginosa isolates

\begin{tabular}{|c|c|c|c|}
\hline strains name & 5 minutes & 10 minutes & 15 minutes \\
\hline Standard & Non-growth & Non-growth & Non-growth \\
\hline Strains1 & Non-growth & Non-growth & Non-growth \\
\hline Strains2 & Non-growth & Non-growth & Non-growth \\
\hline Strains3 & Non-growth & Non-growth & Non-growth \\
\hline Strains4 & Non-growth & Non-growth & Non-growth \\
\hline Strains5 & Non-growth & Non-growth & Non-growth \\
\hline Strains6 & Non-growth & Non-growth & Non-growth \\
\hline Strains7 & Non-growth & Non-growth & Non-growth \\
\hline Strains8 & Non-growth & Non-growth & Non-growth \\
\hline Strains9 & Non-growth & Non-growth & Non-growth \\
\hline Strains10 & Non-growth & Non-growth & Non-growth \\
\hline Strains11 & Non-growth & Non-growth & Non-growth \\
\hline Total & $100 \%$ Non-growth & $100 \%$ Non-growth & $100 \%$ Non-growth \\
\hline
\end{tabular}

Table 2. The effect of the disinfectant Benzalkonium Chloride on Pseudomonas aeruginosa isolates

\begin{tabular}{|c|c|c|c|}
\hline strains name & 5 minutes & 10 minutes & 15 minutes \\
\hline Standard & Non-growth & Non-growth & Non-growth \\
\hline Strains1 & Non-growth & Non-growth & Non-growth \\
\hline Strains2 & Non-growth & Non-growth & Non-growth \\
\hline Strains3 & Non-growth & Non-growth & Non-growth \\
\hline Strains4 & Non-growth & Non-growth & Non-growth \\
\hline Strains5 & Non-growth & Non-growth & Non-growth \\
\hline Strains6 & Non-growth & Non-growth & Non-growth \\
\hline Strains7 & Non-growth & Non-growth & Non-growth \\
\hline Strains8 & Non-growth & Non-growth & Non-growth \\
\hline Strains9 & Non-growth & Non-growth & Non-growth \\
\hline Strains10 & Non-growth & Non-growth & Non-growth \\
\hline Strains11 & Non-growth & Non-growth & Non-growth \\
\hline Total & $100 \%$ Non-growth & $100 \%$ Non-growth & $100 \%$ Non-growth \\
\hline
\end{tabular}

According to Table 3, Cetrimide-C disinfectant has seen approximately 3 growths from 12 isolates in 5 minutes and $100 \%$ bacterial growth in the other 9 strains. In the 10 minutes that most strains came in contact with disinfectants, about 4 strains of bacterial growth were not observed, and in the other 8 strains, 100 bacterial growths were observed. Within 15 minutes, when the strains were much higher in contact with disinfectants, no bacterial growth was observed in 4 strains and 100 bacterial growths were observed in the other 9 strains. According to the Cetrimide-C disinfectant, of the 12 isolates tested for Pseudomonas, 2 were effective: 1 and 10 isolates and it kills bacteria and prevents them from growing $10 \%$, in Separation No. 9, contact with less disinfectant affects the bacteria, which is observed in 5 and 10 minutes $20 \%$ without growth and in 15 minutes it has been ineffective. Separation of No. 2 at low contact 
times, in 5 minutes, was ineffective and in 10 minutes, it had a $10 \%$ effect on killing bacteria in contact with disinfectants for more than 15 minutes, the effect is greater and the bacteria does not grow $20 \%$. In general, the antiseptic effect of Cetrimide-C on 12 strands of Pseudomonas aeruginosa in 5 minutes 20\%, 10 minutes $25 \%$ and 15 minutes $30 \%$ prevents the growth of bacteria and the bacterium has sometimes been able to grow despite the presence of the Cetrimide-C disinfectant.

Table 3. The effect of the disinfectant Cetrimide-C on Pseudomonas aeruginosa isolates

\begin{tabular}{|c|c|c|c|}
\hline strains name & 5 minutes & 10 minutes & 15 minutes \\
\hline Standard & $100 \%$ growth & $100 \%$ growth & $100 \%$ growth \\
\hline Strains1 & $90 \%$ growth & $90 \%$ growth & $90 \%$ growth \\
\hline Strains2 & $100 \%$ growth & $90 \%$ growth & $80 \%$ growth \\
\hline Strains3 & $100 \%$ growth & $100 \%$ growth & $100 \%$ growth \\
\hline Strains4 & $100 \%$ growth & $100 \%$ growth & $100 \%$ growth \\
\hline Strains5 & $100 \%$ growth & $100 \%$ growth & $100 \%$ growth \\
\hline Strains6 & $100 \%$ growth & $100 \%$ growth & $100 \%$ growth \\
\hline Strains 7 & $100 \%$ growth & $100 \%$ growth & $100 \%$ growth \\
\hline Strains8 & $100 \%$ growth & $100 \%$ growth & $100 \%$ growth \\
\hline Strains9 & $90 \%$ growth & $90 \%$ growth & $100 \%$ growth \\
\hline Strains 10 & $80 \%$ growth & $90 \%$ growth & $90 \%$ growth \\
\hline Strains11 & $100 \%$ growth & $100 \%$ growth & $100 \%$ growth \\
\hline Total & $20 \%$ Non-growth & $25 \%$ Non-growth & $30 \%$ Non-growth \\
\hline
\end{tabular}

According to Table 4, the Vico science disinfectant has not been effective in just 5 minutes at $80 \%$, and only in isolating No. 11, $100 \%$ growth of bacteria was observed. Colon growth was not observed at any time of $10 \mathrm{~min}$ or $15 \mathrm{~min}$ and $100 \%$ disinfectant has not caused the growth of bacteria. In other words, the
Vico science disinfectant has been quite effective in 11 Shush from the beginning and in the other Strains, it was not only effective in the first 5 minutes and with more contact, the disinfectant with the bacteria in 10 minutes and 15 minutes has completely destroyed the bacteria.

Table 4. The effect of the disinfectant Vico science on Pseudomonas aeruginosa isolates

\begin{tabular}{|c|c|c|c|}
\hline strains name & 5 minutes & 10 minutes & 15 minutes \\
\hline Standard & Non-growth & Non-growth & Non-growth \\
\hline Strains1 & Non-growth & Non-growth & Non-growth \\
\hline Strains2 & Non-growth & Non-growth & Non-growth \\
\hline Strains3 & Non-growth & Non-growth & Non-growth \\
\hline Strains4 & Non-growth & Non-growth & Non-growth \\
\hline Strains5 & Non-growth & Non-growth & Non-growth \\
\hline Strains6 & Non-growth & Non-growth & Non-growth \\
\hline Strains7 & Non-growth & Non-growth & Non-growth \\
\hline Strains8 & Non-growth & Non-growth & Non-growth \\
\hline Strains9 & Non-growth & Non-growth & Non-growth \\
\hline Strains 10 & Non-growth & Non-growth & Non-growth \\
\hline Strains11 & Growth $100 \%$ & Non-growth & Non-growth \\
\hline Total & $92 \%$ Non-growth & $100 \%$ Non-growth & $100 \%$ Non-growth \\
\hline
\end{tabular}

\section{Confirmation of the Effect of Disinfectants Tested on Pseudomonas aeruginosa Isolates}

The results effects of the disinfectants tested on the Pseudomonas aeruginosa isolates can be seen in Figure 2.
Comparing the Effect of Disinfectants with Pseudomonas aeruginosa Isolates

The results of the present study to investigate the antimicrobial effect of four disinfectants of Hydrocare, Benzalkonium Chloride, Cetrimide-C and Vico science 
against $P$ seudomonas aeruginosa isolates obtaibed from human infections are summarized table 1 . According to the information presented in this table, Hydrocare and Benzalkonium Chloride caused $100 \%$ non- growth at all 3 times of 5, 10 and 15 minutes. Vico science resulted in $100 \%, 100 \%$ and $92 \%$ at 15,10 and 5 minutes bacterial non- growth, respectively. Cetrimide-C showed 20\%, $25 \%$, and $30 \%$ inhabitation of bacterial growth at 5, 10 and 15 minutes, respectively, and using ANOVA statistical test the difference in the antiseptic power of Citrimide-C was statistically significant $(P<0.05)$.

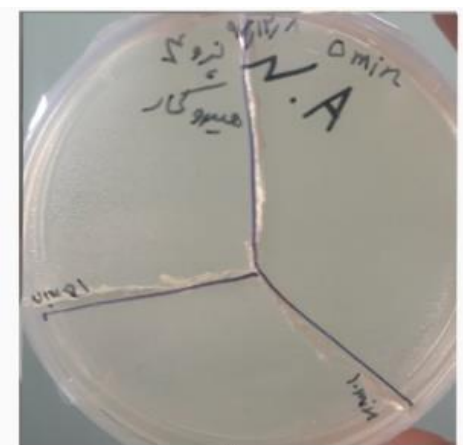

A

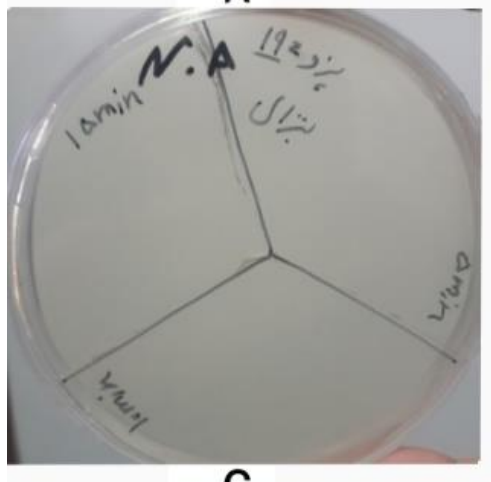

C

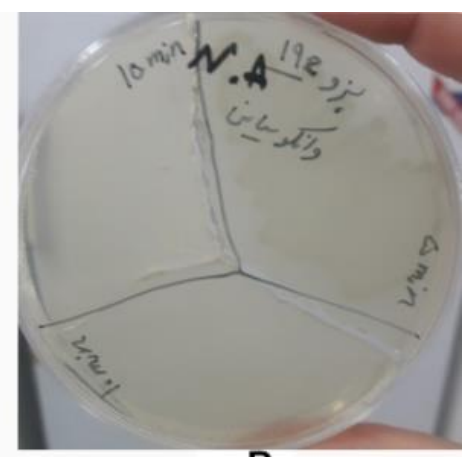

B

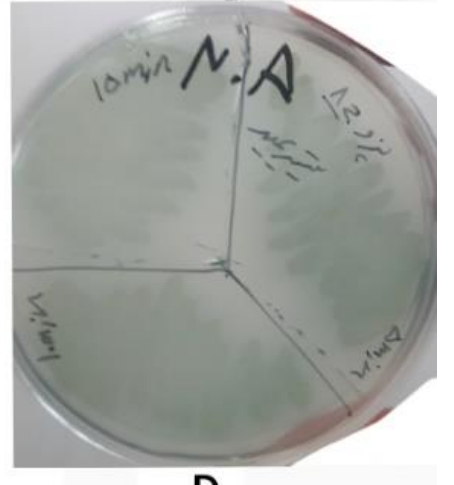

D

Figure 2. Confirmation of the Effect of Disinfectants on Pseudomonas aeruginosa

A: The effect of the disinfectant Hydrocare on Strains4, at all three times, the bacteria did not fully grow for 5, 10, and 15 minutes.

B: The effect of the disinfectant Vico science on Strains11, (In the form of: $19 z$ sample number in the hospital), the disinfectant did not work for 5 minutes and the bacteria grew Colonial growth was not observed at $10 \mathrm{~min}$ and $15 \mathrm{~min}$, and the disinfectant had a $100 \%$ effect.

C: The effect of the disinfectant Benzalkonium Chloride on Strains11, at all three times, the bacteria did not fully grow for 5 , 10 , and 15 minutes.

D: The effect of the disinfectant Cetrimide-C on Strains 8, At all three times, the bacteria were fully formed for 5, 10 and 15 minutes.

Table 5. The effect of the disinfectants on Pseudomonas aeruginosa isolates (12 strains)

\begin{tabular}{|c|c|c|c|}
\hline Disinfectant name & 5 minutes & 10 minutes & 15 minutes \\
\hline Hydrocare & $100 \%$ Non-growth & $100 \%$ Non-growth & $100 \%$ Non-growth \\
\hline Benzalkonium chloride & $100 \%$ Non-growth & $100 \%$ Non-growth & $100 \%$ Non-growth \\
\hline Vico sience & $92 \%$ Non-growth & $100 \%$ Non-growth & $100 \%$ Non-growth \\
\hline Cetrimide- $\mathrm{C}$ & $20 \%$ Non-growth & $25 \%$ Non-growth & $30 \%$ Non-growth \\
\hline
\end{tabular}

In this study, it was very difficult to determine which disinfectant was the most potent; although the results from Cetrimide- $C$ were very poor, the three other disinfectants did not differ significantly. The results showed that Cetrimide- $C$ may not be suitable and useful for control of Pseudomonas aeruginosa in health centers and hospitals and if is used according to the manufacture instructions, it will not only has the ability to inhibit bacterial growth but can also cause irreparable damages. 
Along with the present study, other studies have been carried out including:

El-Bana et al. (2019) studied the effect of non-lethal concentrations of Benzalkonium Chloride on the antibiotic resistance, growth pattern and biofilm formation of Pseudomonas aeruginosa isolates and the results indicated that $60 \%$ of isolates showed increased biofilm formation and antibiotic resistance (25).

Montagna et al (2019) evaluated the effect of five hospital antibacterial disinfectants (Phenolic compounds, Quaternary Ammonium compounds, Sodium hypochlorite, alcoholic compounds and Hydrogen peroxide) on Pseudomonas aeruginosa, Staphylococcus aureus and Enterococcus. The results showed that Hydrogen peroxide at all concentrations was the only disinfectant that had inhibitory effect against all tested microorganisms (1).

Vijaya et al. (2016) addressed the issue of increasing the drug resistance of Pseudomonas aeruginosa clinical strains against common disinfectants in the laboratory, it has been shown that aerogenous strains increase by $22 \%$ multidrug resistance as well as decrease resistance to benzalkonium chloride disinfectant (26). Medical environments, etc., may be infected with microorganisms, which are disinfected with disinfectants such as benzalkonium chloride. Of course, various factors can be involved in the resistance of pathogens to this disinfectant.

Hourai et al. (2004) studied the disinfectant effect of benzalkonium chloride and chlorhexidine on bacterial biofilm formation, the bacterium Pseudomonas aeruginosa is more resistant to the disinfectant benzalkonium chloride. The results of the study by Hourai et al. Did not show much agreement with the present study, because in our study, benzalkonium chloride showed a $100 \%$ inhibitory effect against the growth of Pseudomonas aeruginosa bacteria. The reason for this discrepancy may be due to differences in the methods used in the two studies as well as differences in the studies studied (27).

Carson et al. (1972) examined the factors affecting the resistance of Pseudomonas aeruginosa purified from a hospital center to disinfectants, they found that Pseudomonas aeruginosa was inactivated by contact with glutaraldehyde chloride, acetic acid, and a combination of ammonium quaternary, this inactivation depends on factors such as the growth stage at the time of contact with the disinfectant, the nature of the disinfectant, and the incubation temperature. The results of a study by Carson et al. On the effect of ammonium quaternary compound on Pseudomonas aeruginosa were consistent with the results of the present study (28).
Olasehinde et al. (2008) addressed the effect of Savlon, Dettol, la-naphtho disinfectants on Pseudomonas aeruginosa, Salmonella typhoid and Proteus bacteria. In this study, the concentration of disinfectants was increased by $25 \%$ and the results showed that all disinfectants had weaker inhibitory inhibition than microorganisms in the early stages, As the concentration increased, the disinfectant effect increased (29). The findings of this study on the weakness of the antimicrobial effect of Saulen are in line with the findings of the present study.

Hassan et al. (2008) examined the effect of a number of common hospital disinfectants against Pseudomonas aeruginosa isolated from patients' infections. The strains studied showed resistance to the three ethanol disinfectants, Jeremy Side-P and Pidon Ayodine with different dilutions in the surface test with different percentages and only Cetrimide-C was able to completely eliminate all strains by consuming 1 to 30 (30). The reason for the discrepancies between the findings of this study and the results of the present study is that the concentration of 1 to 30 Savlon used in the study of Hassan et al. Is much higher than the concentration recommended by the manufacturing plant in the present study.

Gasparini et al. (1995) discussed the effect of Virkon $\mathrm{S}$ on Pseudomonas aeruginosa, Escherichia coli, Staphylococcus aureus and Spor bacillus bacteria, and hepatitis $B$ surface antigen, Virkon $S$ was in contact with the mentioned bacteria for $5,10,20,30,40,50$, 60 minutes and they found that Virkon $\mathrm{S}$ was able to destroy the surface antigen of hepatitis $B$. They also found that Virkon S was suitable for destroying spores. The results of this study showed that Virjon $\mathrm{S}$ is a very fast disinfectant. The results of the Gasparini et al. Study of the effect of vacuoussion on Pseudomonas aeruginosa are fully consistent with the results of the present study (31).

\section{Acknowledgment}

The present study is based on a Master's thesis in Bacteriology at Shahrekord University. The authors are grateful to the personnel of the Microbiology Laboratory of the Faculty of Veterinary Medicine, Shahrekord University.

\section{Conflict of Interest}

Authors declared no conflict of interests. 


$$
\begin{aligned}
& \text { مجله ميكروبشناسى يزشكى ايران }
\end{aligned}
$$

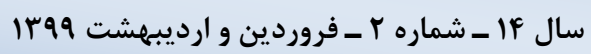

$$
\begin{aligned}
& \text { Journal homepage: www.ijmm.ir }
\end{aligned}
$$

مقاله

\title{
ارزيابى تأثير تعدادى از ضدعفونىكنندهاى تجارى برجدايههاى سودوموناس آيروجينوزا جدا شده از موارد عفونت انسانى
}

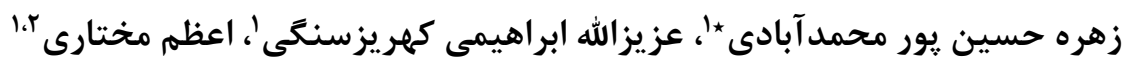

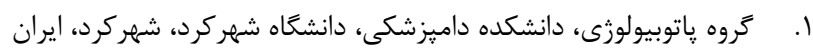

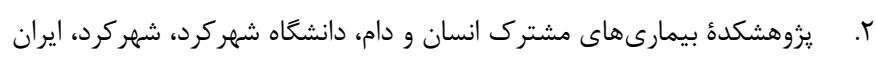

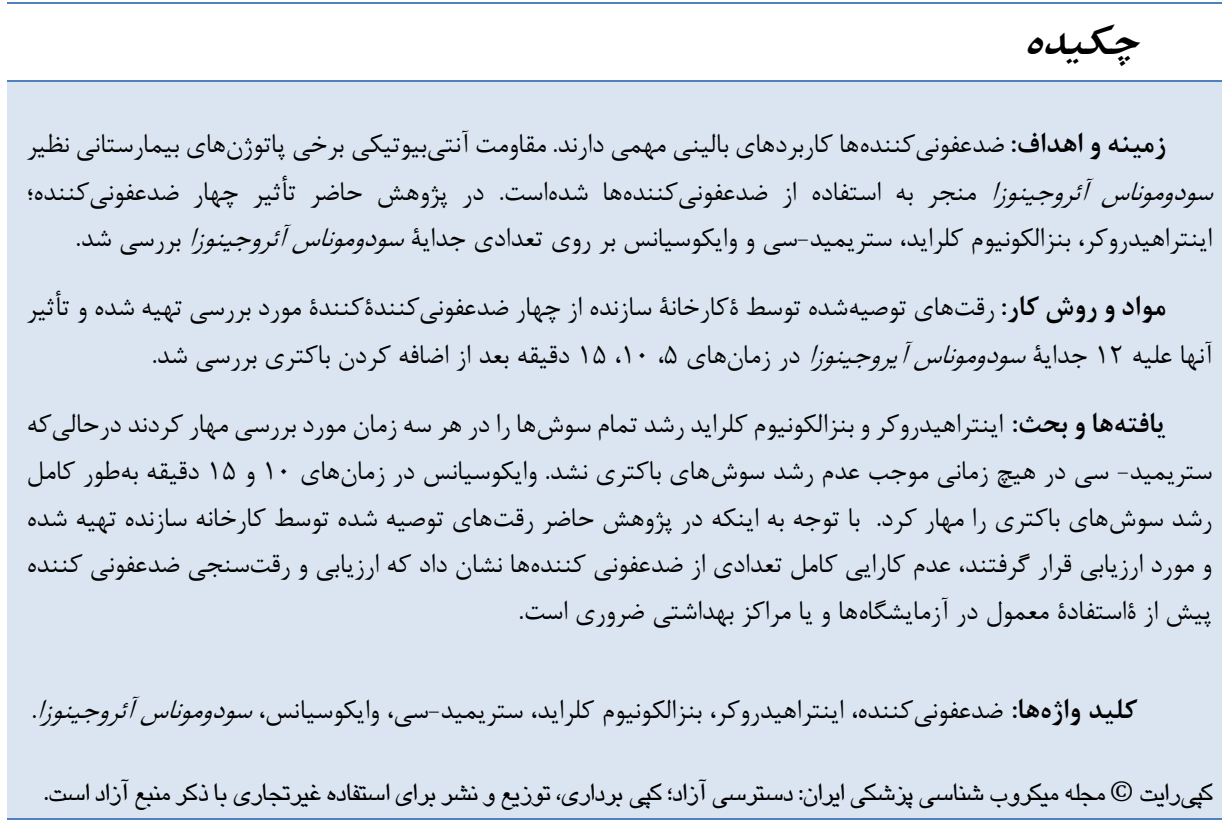

اطلاعات مقاله

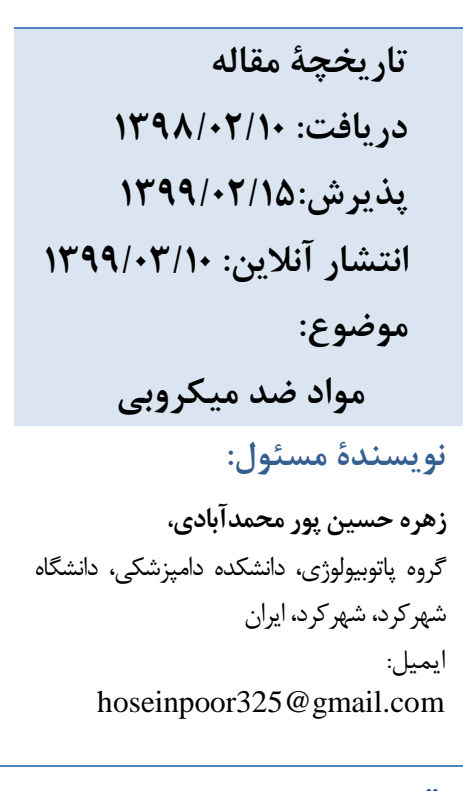

مقلمهـ

كه منجر به عفونتهاى بيمارستانى بلويزه در بخش مراقبتهاى

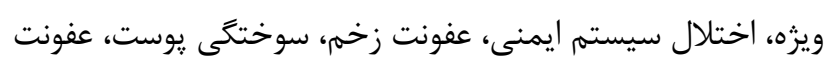

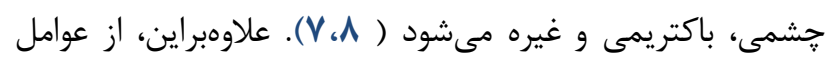

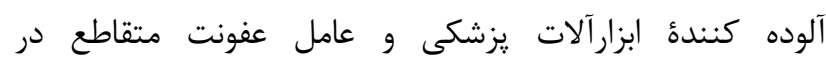
بيمارستانها است (9). روشهاى ضدعفونى كننده در بيمارستانها اصلىترين نوع مداخله در برابر ميكروار كانيسمهاى بيمارىزا به شمار مىرود (•). براساس اطلاعاتى كه توسط مركز ارويايى بيشخيرى و كنترل بيمارىها (ECDC) ززارش شده است، هر ساله حدود . . . . . نفر در ارويا در اثر عفونتهاى ناشى از باكترىهاى مقاوم به جند دارو جان خود را از دست مىدهند (1)). در ايران در سال

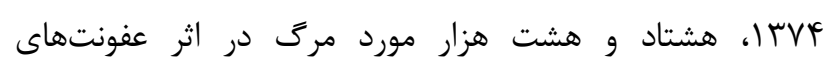

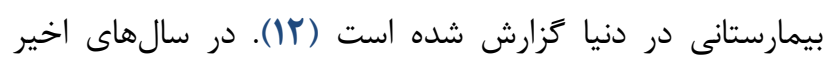

عفونتهاى بيمارستانى باعث عوارض و مرگ و مير قابل ملاحظهاى در سراسر جهان مىشوند و ارگانيسمهاى بيمارىزا كه مسئول جنين عفونتهايى هستند ميىتوانند در برابر عوامل ضد ميكروبى مقاومت ايجاد كنند. درك فعاليت ضدعفونى كنندهها در برابر باكترىهاى زيست محيطى و باكتريايى محيطى بسيار مهرم بوده

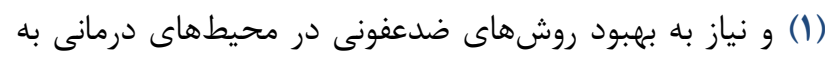
فراوانى احساس مىشود (Y). سودوموناس آئروجينوزا يك باكترى

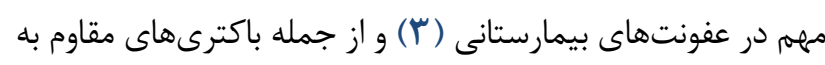
آنتى بيوتيكها است (F) كه باعث عفونتهاى ناشى از مقاومت به به ״ند دارو مىشود (ه). سودوموناس آئروجينوزا بهلحاظ بيمارىزايى و سازگارى در شرايط مختلف محيطى از اهميت بالايى برخوردار

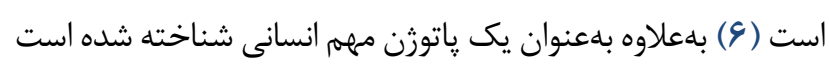


براى تأييد تشخيص باكترى رشد كرده، در ابتدا نمونهها از

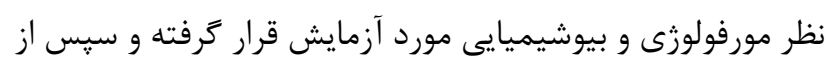

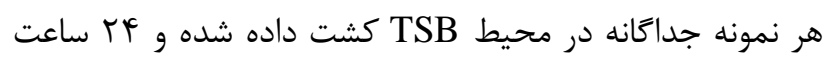

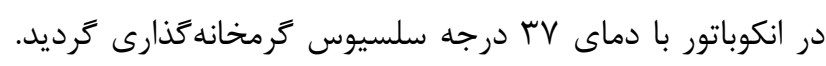

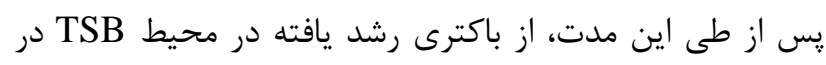

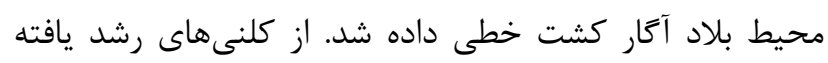
كسترش تهيه شده و تستهاى كاتالاز و اكسيداز انجام گرىديد

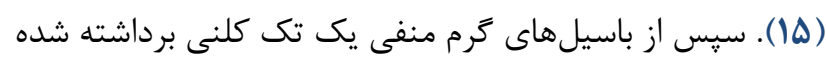

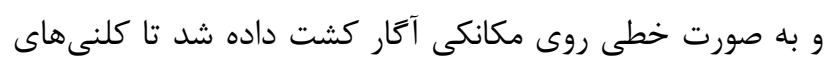

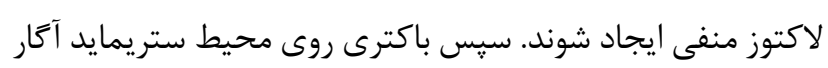

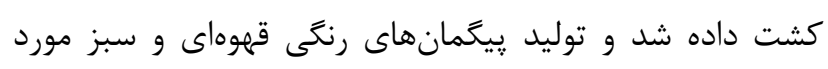

بررسى قرار داده شد (1) - (1).

سيس از كلنىهاى رشد يافته در محيط TSI كشت داده شد

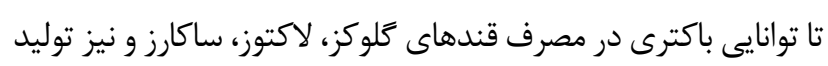

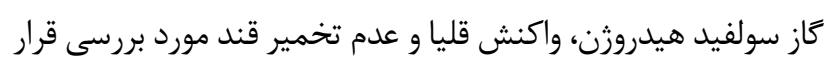

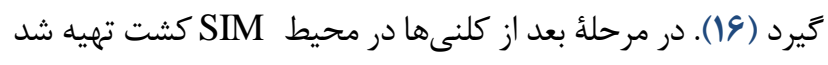

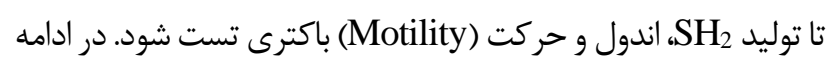

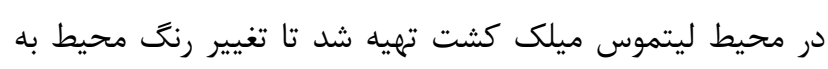
صورتى با لختهاى تكهتكه شده مشاهده شود (ه(1).

بررسى اثر ضدعفونى كنندهها بر روى سويههاى

\section{سودوموناس آئروجينوزا}

اينتر اهيدروكر) (Hydrocare) يك پياك كننده و ضدعفونى كنندة

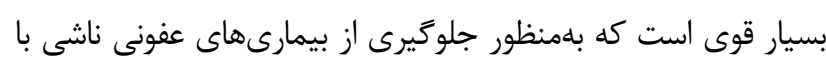

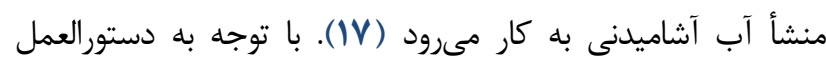

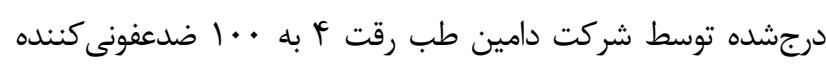

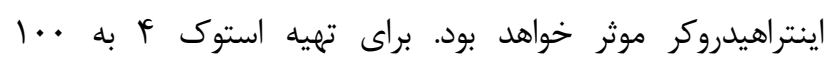

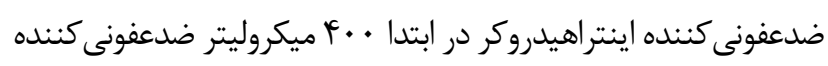

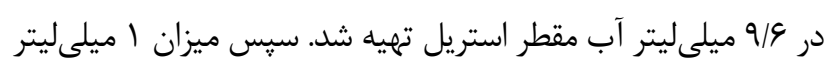

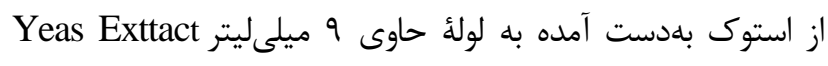
Broth

وايكوسيانس (Vico sience) يك ضدعفونى كننده و از بين

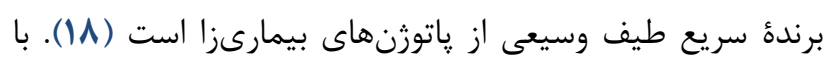

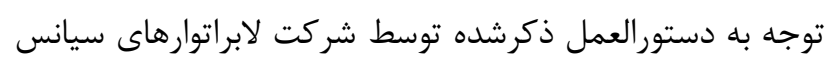
(LS)

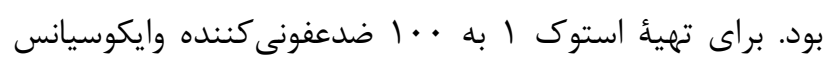

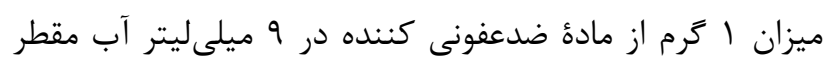

تحقيقات متعددى در كشورهاى مختلف در خصوص ارزيابى تأثير

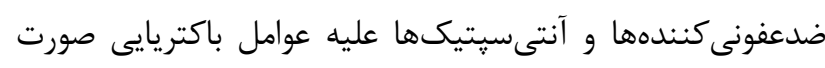

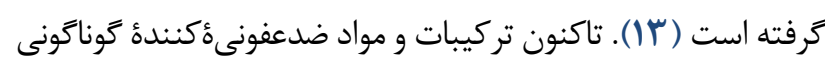
توسط شركتهاى مختلف ساخته شده كه هر يك داراى معايب و و

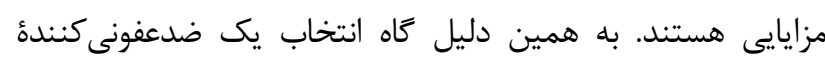
مناسب كار مشكلى است خرا كه شركتهاى سازنده در اغلب موارد

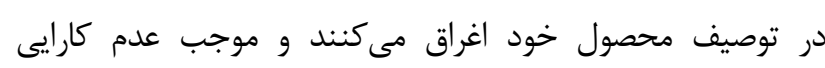

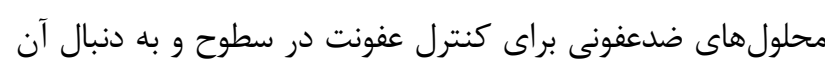

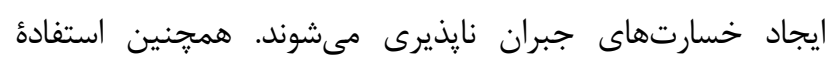

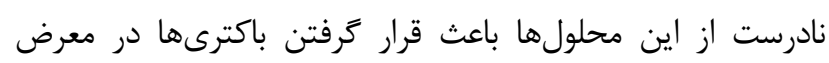

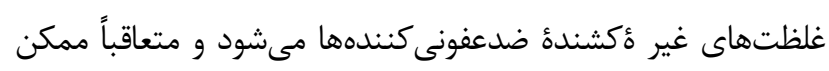

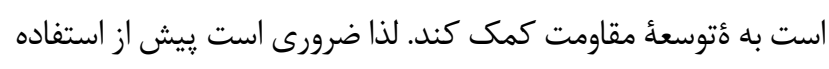

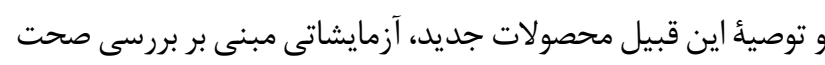

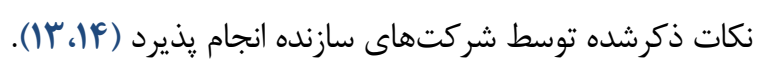
با توجه به موارد ذكرشده و اهميت سودوموناس آئروجينوزا در

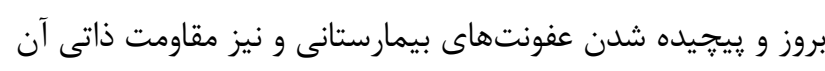

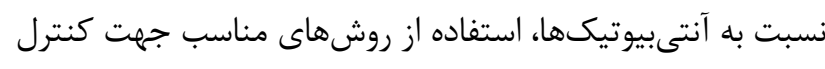

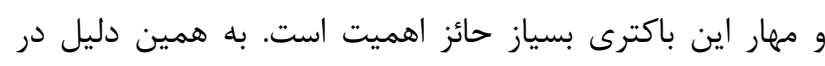

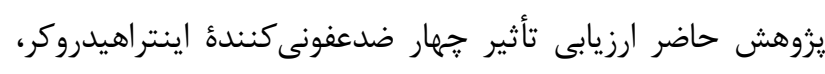

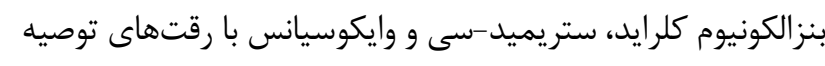

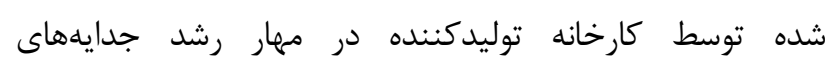

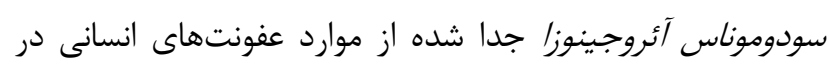

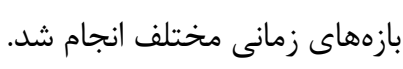

\section{روش يزورهش}

\section{جمع آورى نمونه}

براى انجام اين يزوهش در ارديبهشت ماه لو ب ا ا، هفت سويه

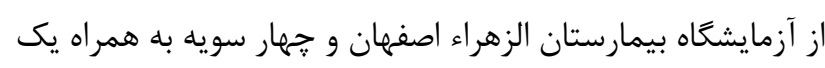

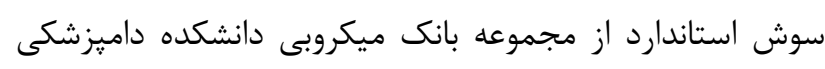
دانشكاه شهر كرد تهيه شد.

\section{تأييد نمونه}

نمونههاى باكتريايى تهيهشده با كشت استريك روى مكانكى

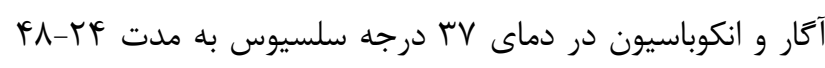

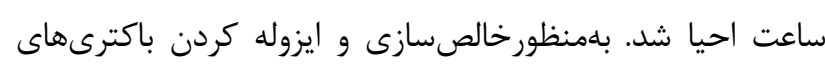

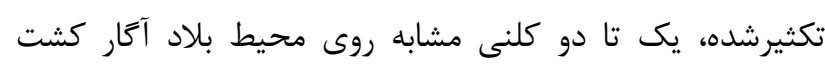

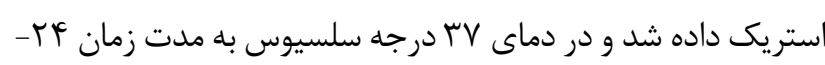

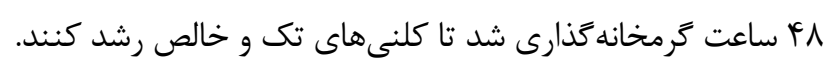


CFU/ML ) ميكروليتر از سوش باكترى با غلظت

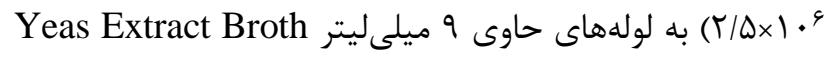
كه مخلوط با استوك ضدعفونى كننده بود افزوده شد و و كاملاً مخلوط گرديد. از زمان مخلوط شدن رقت تهيه شده از ماده ضد ضد صدون

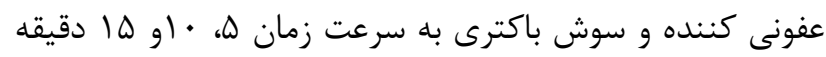

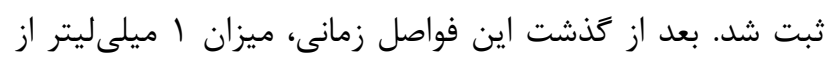
لولههاى حاوى Yeas Extract Broth ، ضدعفونى كننده و باكترى به ب ميلىليتر BHI Broth افزوده و يس از مخلوط شدن كامل، به مدت F أروز در انكوباتور با دماى VV درجه سلسيوس قرار گرفت.

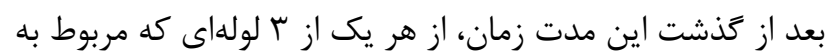
هر يك از زمانهاى مورد بررسى بود، يك حلقه آنس برداشته و بر

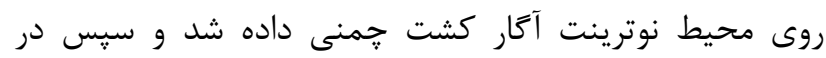
انكوباتور با دماى TV درجه سلسيوس به مدت بf ساعت قرار گرفت. در انتها رشد يا عدم رشد كلنىهاى باكترى در يليتهاى

$$
\text { نوترينت آحار مورد بررسى قرار زرفت. }
$$

\section{بافته ها و بحث}

\section{تأييد سويلهاى باكترى سودوموناس آئروجينوزا}

نتايج آزمونهاى بيوشيميايى انجام گرفته روى كلنىهاى

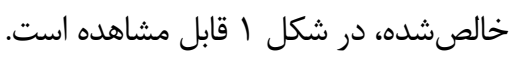

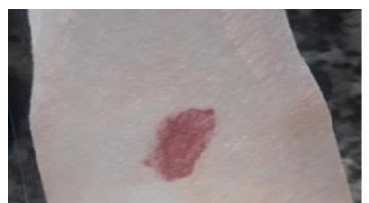

A

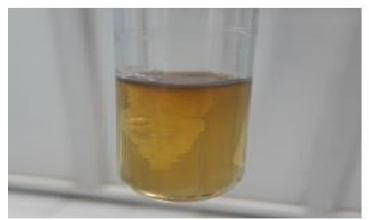

C

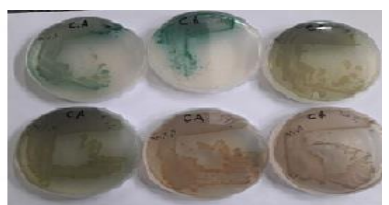

B

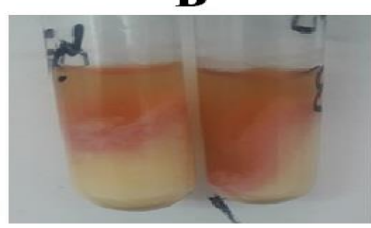

D
شكل ا. تأييد سويههاى باكترى سودوموناس آئروجينوزا

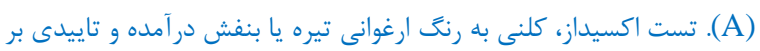

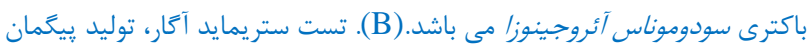

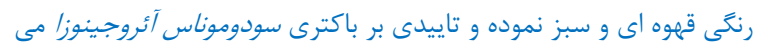

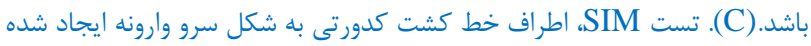

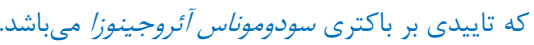

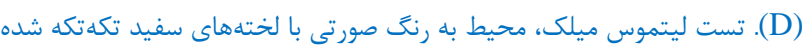

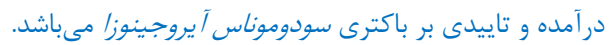

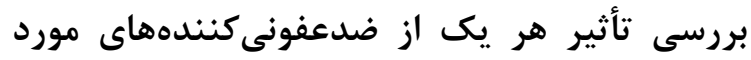
آزمايش بر روى جدايههاى سودوموناس آئروجينوزا
استريل حل شد. سيس ميزان ا ميلىليتر از استوك تهيه شده در 9 ميلى ليتر محيط Yeas Extract Broth حل شد. بنزالكونيوم كلرايد يك بايوسايد آمونيوم :ههارتايى با طيف كسترده است (9 (1) و كاربردهاى مختلفى در ضدعفونى، صنعت

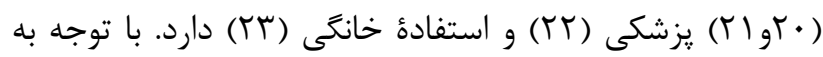
دستور العمل درجشده بر روى ضدعفونى كننده بنزالكونيوم كلرايد با شماره يروانه 93-140-D.T از سازمان داميزشكى كشور رقت 1

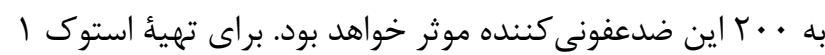

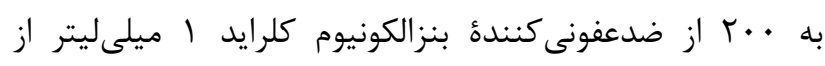
ضدعفونى كننده در 19 ميلى ليتر آب مقطر استريل حل شد. سيس حجم ا ميلىليتر از استوك بهدستآمده در 9 ميلىليتر محيط Yeas Extract Broth

ستريميد-سى يا ساولن (Savlon) يك ضدعفونى كننده با استفاده گسترده است كه براى ضدعفونى و پانسمان زخمها و

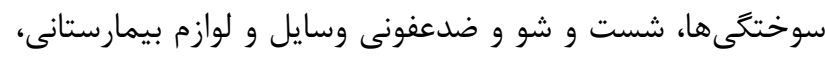
ضدعفونى اتاق عمل و... به كار مىرود و يكى باكترى كش قوى لـى، ايمن و فاقد اثرات سمى است (TF). با توجه به دستورالعمل درج

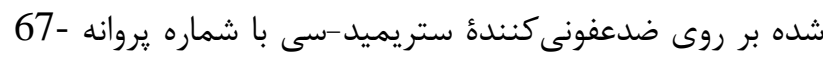

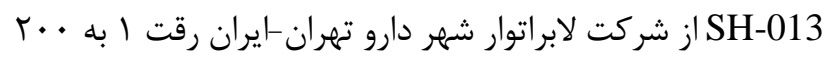

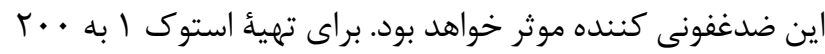
از ضدعفونى كننده ستريميد-سى ا ميلىليتر از ضدعفونى كننده در 19 ميلىليتر آب مقطر استريل حل شد. سيس حجم 1

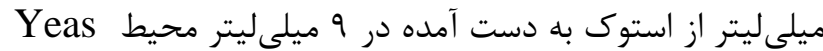
Extract Broth

براى بررسى اثر ضدعفونى كنندهها بر روى سويههاى باكترى

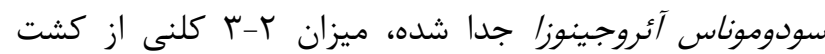
خالصشده هر سوش برداشته و در لولههاى حاوى محيط TSB

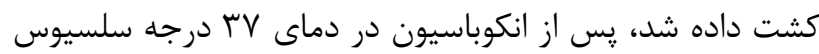

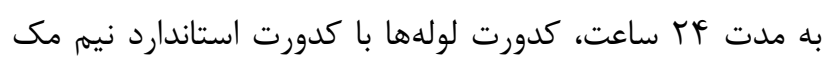

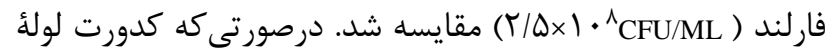

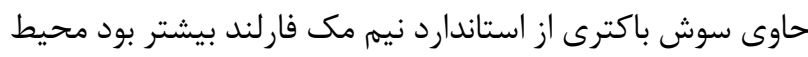
اضافه مىشد و جنانجه كدورت لوله حاوى سوش باكترى از از استاندارد نيم مك فارلند شفافتر بود به آن كلنى باكترى اضافه مى گرديد تا غلظت لولهها برابر با استاندارد نيم مك فارلند شود. در ادامه ميزان · · إميكروليتر از محيط نيم مك فارلند به دست آمده به 9/9 ميلىليتر محيط TSB اضافه شد تا غلظت

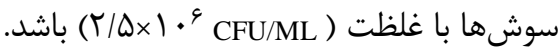


با توجه به جدول الدر زمانهاى ه ، ، · و ها دقيقه در هيج كدام از

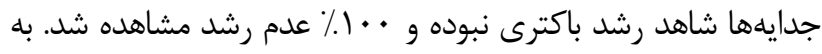

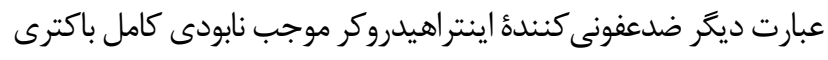

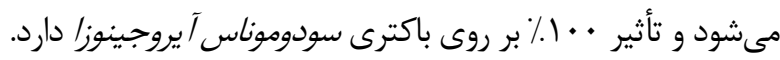

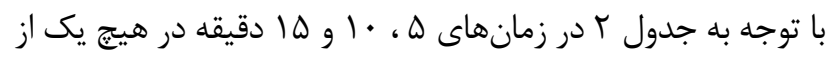

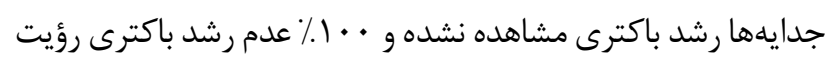

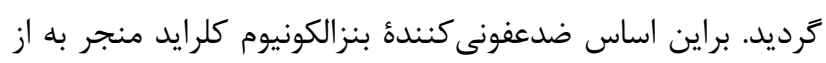

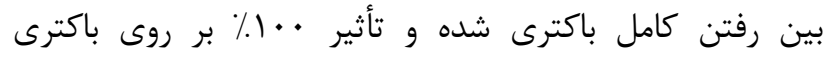
سودوموناس آيروجينوزا داشته است.
نتايج بهدست آمده از اين يزوهش جهت بررسى اثر ضدميكروبى

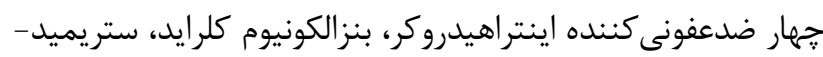

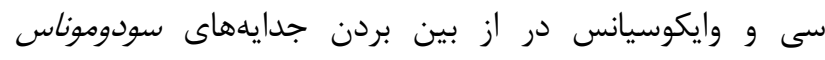

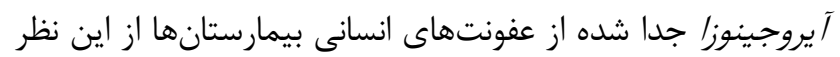

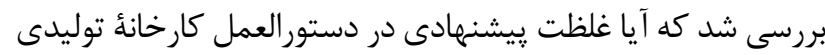

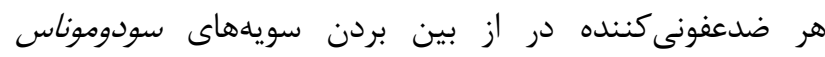

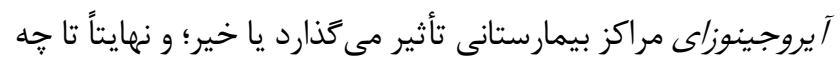

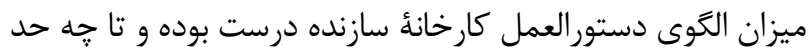

$$
\text { صرفاً انحرافى براى معرفى محصولات بوده است. }
$$

\begin{tabular}{|c|c|c|c|}
\hline زمان ها دقيقه & زمان ·ا دقيقه & زمان ه دقيقه & نام سوشها \\
\hline عدم رشد باكترى & عدم رشد باكترى & عدم رشد باكترى & استاندارد \\
\hline عدم رشد باكترى & عدم رشد باكترى & عدم رشد باكترى & جدايه 1 \\
\hline عدم رشد باكترى & عدم رشد باكترى & عدم رشد باكترى & جدايه r \\
\hline عدم رشد باكترى & عدم رشد باكترى & عدم رشد باكترى & جدايه r \\
\hline عدم رشد باكترى & عدم رشد باكترى & عدم رشد باكترى & جدايه F \\
\hline عدم رشد باكترى & عدم رشد باكترى & عدم رشد باكترى & جدايه هـ \\
\hline عدم رشد باكترى & عدم رشد باكترى & عدم رشد باكترى & جدايه 9 \\
\hline عدم رشد باكترى & عدم رشد باكترى & عدم رشد باكترى & جدايه V \\
\hline عدم رشد باكترى & عدم رشد باكترى & عدم رشد باكترى & جدايه 1 \\
\hline عدم رشد باكترى & عدم رشد باكترى & عدم رشد باكترى & جدايه 9 \\
\hline عدم رشد باكترى & عدم رشد باكترى & عدم رشد باكترى & جدايه •1 \\
\hline عدم رشد باكترى & عدم رشد باكترى & عدم رشد باكترى & جدايه II \\
\hline •.|٪ عدم رشد & ..1\% عدم رشد & •.|٪ عدم رشد & جمع جدايهها \\
\hline
\end{tabular}

جدول r. تاثير ضدعفونى كننده بنزالكونيوم كلرايد بر جدايههاى سودوموناس آيروجينوزا

\begin{tabular}{|c|c|c|c|}
\hline زمان ها دقيقه & زمان •ا دقيقه & زمان ه دقيقه & نام سوشىها \\
\hline عدم رشد باكترى & عدم رشد باكترى & عدم رشد باكترى & استاندارد \\
\hline عدم رشد باكترى & عدم رشد باكترى & عدم رشد باكترى & جدايه ا \\
\hline عدم رشد باكترى & عدم رشد باكترى & عدم رشد باكترى & جدايه r \\
\hline عدم رشد باكترى & عدم رشد باكترى & عدم رشد باكترى & جدايه r \\
\hline عدم رشد باكترى & عدم رشد باكترى & عدم رشد باكترى & جدايه F \\
\hline عدم رشد باكترى & عدم رشد باكترى & عدم رشد باكترى & جدايه هـ \\
\hline عدم رشد باكترى & عدم رشد باكترى & عدم رشد باكترى & جدايه 9 \\
\hline عدم رشد باكترى & عدم رشد باكترى & عدم رشد باكترى & جدايه V \\
\hline عدم رشد باكترى & عدم رشد باكترى & عدم رشد باكترى & جدايه 1 \\
\hline عدم رشد باكترى & عدم رشد باكترى & عدم رشد باكترى & جدايه 9 \\
\hline عدم رشد باكترى & عدم رشد باكترى & عدم رشد باكترى & جدايه •1 \\
\hline عدم رشد باكترى & عدم رشد باكترى & عدم رشد باكترى & جدايه || \\
\hline •.|. عدم رشد & •.|٪ عدم رشد & •.|٪ عدم رشد & جمع جدايهها \\
\hline
\end{tabular}


جدائُ شماره 9 تماس كمتر ضدعفونى كننده بر باكترى تأثير كذار

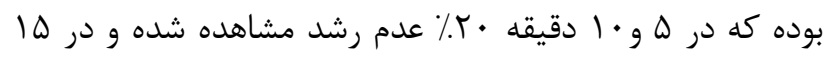

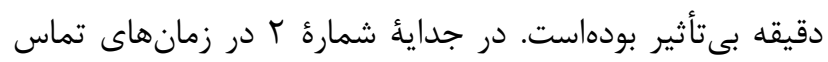

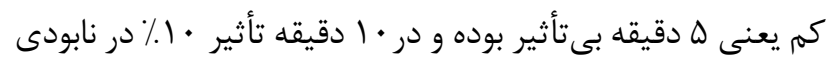

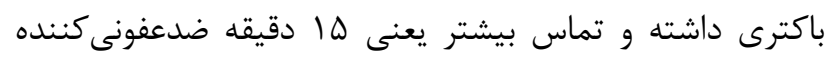
تاثير بيشتر شده و باكترى • ·r٪ عدم رشد داشته است. در مجموع مى توان كَفت تأثيرى كه ضدعفونى كنندة ستريميد-

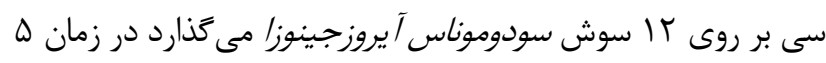

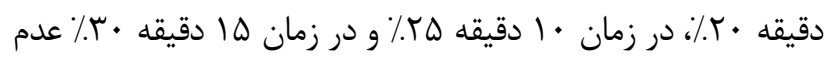

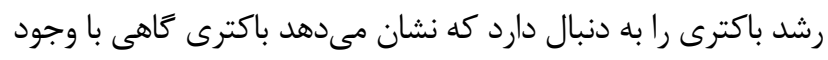

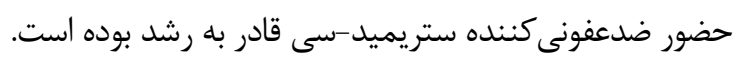

با توجه به جدول ب ضدعفونى كننده ستريميد-سى در بين

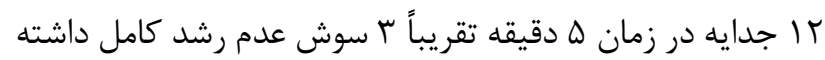

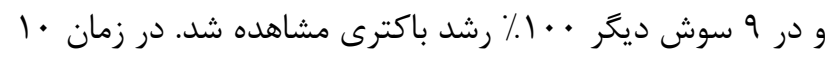

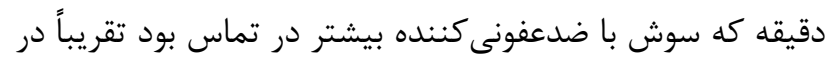

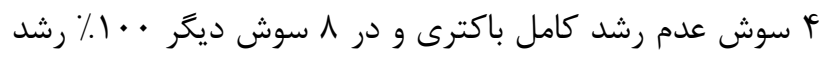

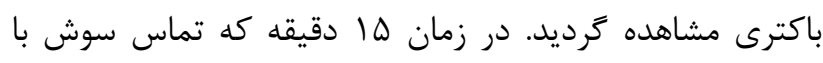

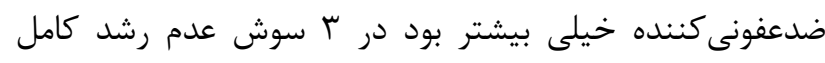

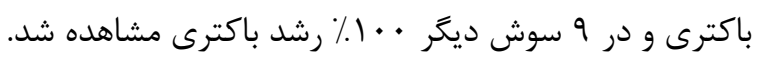
براين اساس ضدعفونى كننده ستريميد-سى از بين با جا جدايه

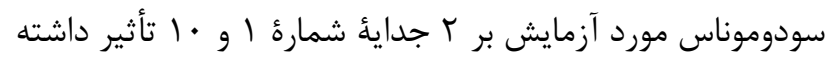

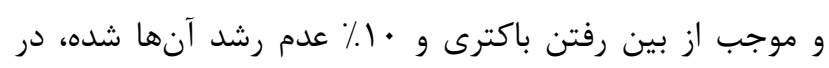

جدول r. تاثير ضدعفونى كننده ستريميد-سى بر جدايههاى سودوموناس آيروجينوزا

\begin{tabular}{|c|c|c|c|}
\hline زمان ها دقيقه & زمان •ا دقيقه & زمان ه دقيقه & نام سوشها \\
\hline •. (1) رشد باكترى & . . 1٪ رشد باكترى & . . 1٪ رشد باكترى & استاندارد \\
\hline •9٪ رشد باكترى & •9٪ رشد باكترى & • 9٪ رشد باكترى & جدايه 1 \\
\hline •^^/ رشد باكترى & •9٪ رشد باكترى & . . 1\% رشد باكترى & جدايه r \\
\hline •. إ٪ رشد باكترى & . . 1٪ رشد باكترى & . . 1. رشد باكترى & جدايه r \\
\hline • . 1٪ رشد باكترى & • . 1٪ رشد باكترى & •. . . رشد باكترى & جدايه F \\
\hline • . 1٪ رشد باكترى & •. . . رشد باكترى & •. . 1\% رشد باكترى & جدايه هـ \\
\hline •. (1) رشد باكترى & •. . 1٪ رشد باكترى & •. . . رشد باكترى & جدايه \\
\hline •. (1٪ رشد باكترى & •. . 1\% رشد باكترى & •. . . رشد باكترى & جدايه V \\
\hline •. (1) رشد باكترى & •. 1. رشد باكترى & . . 1٪ رشد باكترى & جدايه 1 \\
\hline •. (1) رشد باكترى & •9٪ رشد باكترى & •9٪ رشد باكترى & جدايه 9 \\
\hline •9٪ رشد باكترى & •9٪ رشد باكترى & • •.٪ر شد باكترى & جدايه . \\
\hline •. (1) رشد باكترى & •. . 1\% رشد باكترى & • . 1. رشد باكترى & جدايه || \\
\hline 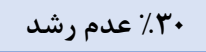 & هr\% عدم رشد & 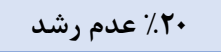 & جمع جدايهها \\
\hline
\end{tabular}

به عبارتى ضدعفونى كننده وايكوسيانس در 11 سوش از ابتدا

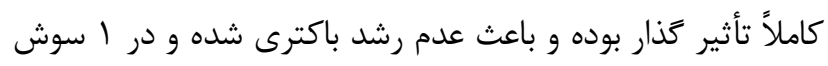

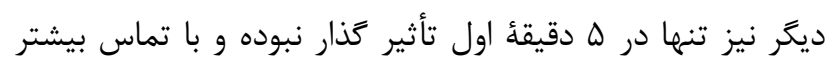

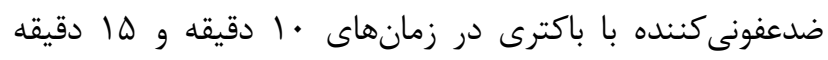
موجب نابودى كامل باكترى شده است.
با توجه به جدول \& ضدعفونى كننده وايكوسيانس فقط در

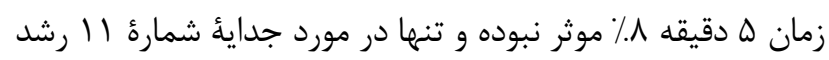

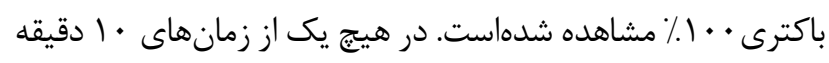

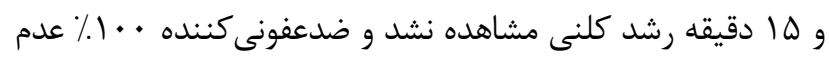
رشد باكترى را به دنبال داشت.

جدول f. تاثير ضدعفونى كننده وايكوسيانس بر جدايههاى سودوموناس آيروجينوزا

\begin{tabular}{|c|c|c|c|}
\hline زمان ها دقيقه & زمان •ا دقيقه & زمان ه دقيقه & نام سوشها \\
\hline عدم رشد باكترى & عدم رشد باكترى & عدم رشد باكترى & استاندارد \\
\hline عدم رشد باكترى & عدم رشد باكترى & عدم رشد باكترى & جدايه ا \\
\hline عدم رشد باكترى & عدم رشد باكترى & عدم رشد باكترى & جدايه r \\
\hline عدم رشد باكترى & عدم رشد باكترى & عدم رشد باكترى & جدايه r \\
\hline عدم رشد باكترى & عدم رشد باكترى & عدم رشد باكترى & جدايه f \\
\hline
\end{tabular}




\begin{tabular}{|c|c|c|c|}
\hline زمان ها دقيقه & زمان •ادقيقه & زمان ه دقيقه & نام سوشها \\
\hline عدم رشد باكترى & عدم رشد باكترى & عدم رشد باكترى & جدايه هـ \\
\hline عدم رشد باكترى & عدم رشد باكترى & عدم رشد باكترى & جدايه 9 \\
\hline عدم رشد باكترى & عدم رشد باكترى & عدم رشد باكترى & جدايه V \\
\hline عدم رشد باكترى & عدم رشد باكترى & عدم رشد باكترى & جدايه 1 \\
\hline عدم رشد باكترى & عدم رشد باكترى & عدم رشد باكترى & جدايه 9 \\
\hline عدم رشد باكترى & عدم رشد باكترى & عدم رشد باكترى & جدايه +1. \\
\hline عدم رشد باكترى & عدم رشد باكترى & • . . رشد باكترى & جدايه II \\
\hline ..1\% عدم رشد & 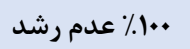 & ז9\%٪ عدم رشد & جمع نمونهها \\
\hline
\end{tabular}

سودوموناس آئروجينوزا جدا شده از عفونتهاى انسانى در جدول

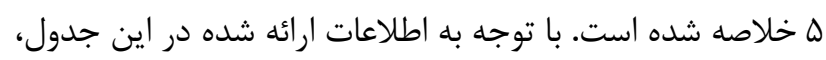

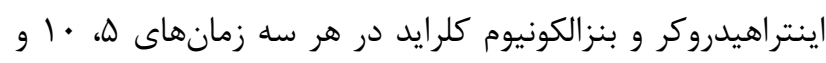

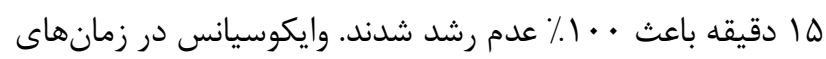

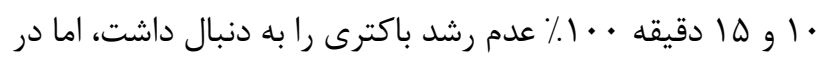

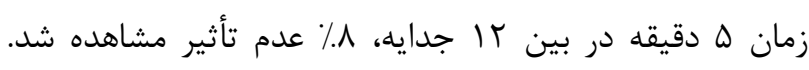

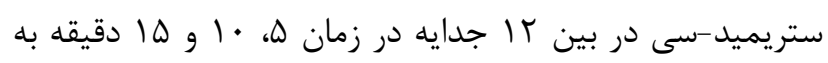

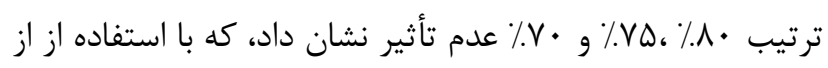

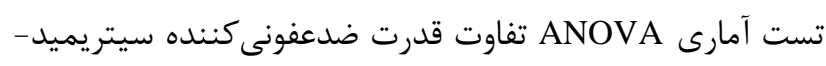

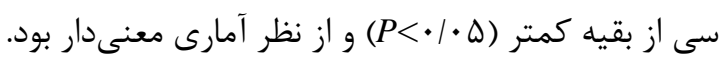

تاييد تأثير ضدعفونى كنندههاى مورد آزمايش بر روى جدايههاى سودوموناس آئروجينوزا

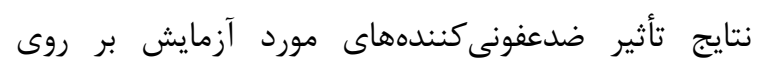
جدايههاى سودوموناس آئروجينوزا، در شكل r قابل مشاهده است. مقايسه تأثير ضدعفونى كنندههاى مورد آزمايش بر روى جدايههاى سودوموناس آئروجينوزا

نتايج بدست آمده از اين يزوهش جهت بررسى اثر

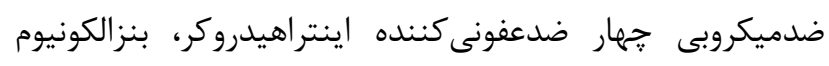

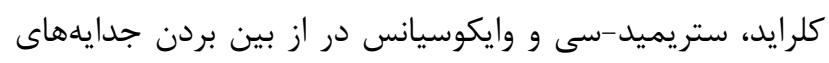
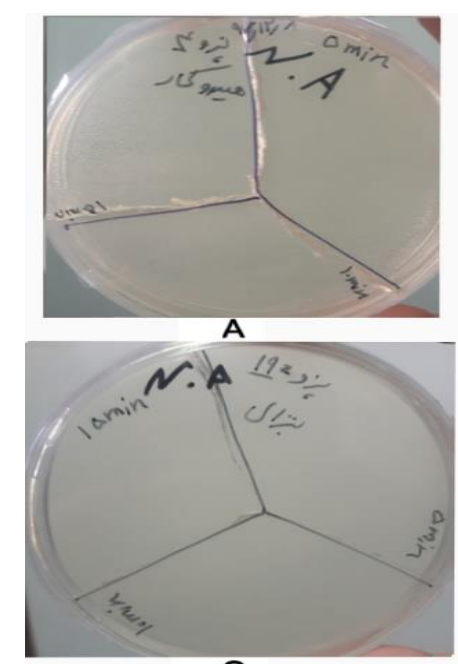

C
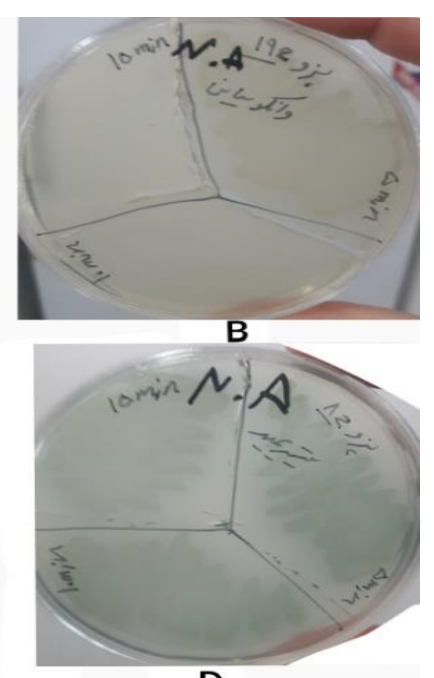

D

شكل ا. تأييد تأثير ضدعفونى كنندهها بر جدايههاى سودوموناس آئروجينوزا

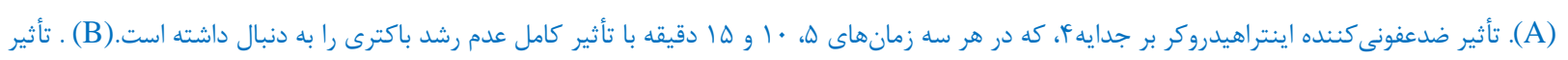

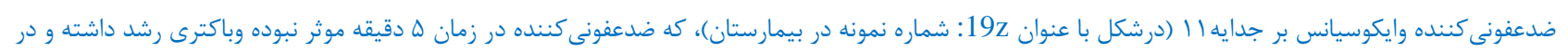

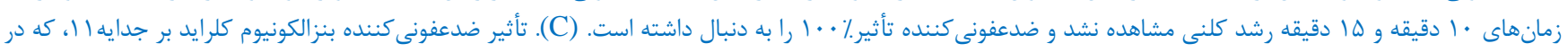

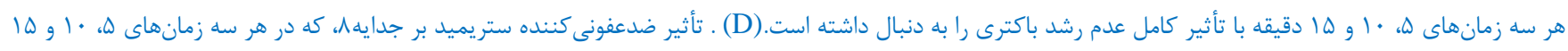
دقيقه با بدون تأثير بوده و رشد باكترى را به دنبال داشته است. 
جدول ه. مقايسه تأثير ضدعفونى كنندههاى مورد آزمايش بر روى جدايههاى سودوموناس آئروجينوزا (rا سوش)

\begin{tabular}{|c|c|c|c|}
\hline زمان ها دقيقه & زمان •ا دقيقه & زمان ه دقيقه & نام ضدعفونى كننده \\
\hline 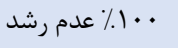 & • . . عدم رشد & ..عدم رشد & اينتراهيدروكر \\
\hline • . 1\% عدم رشد & . . 1\% عدم رشد & . . 1\% عدم رشد & بنزاكونيوم كلرايد \\
\hline • • 1. عدم رشد & 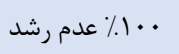 & 9 9 \% عدم رشد & وايكوسيانس \\
\hline • • م/ عدم رشد & ه厂\%٪ عدم رشد & • r. عدم رشد & ستريميد-سى \\
\hline
\end{tabular}

ممكن است محيطهاى يزشكى و... درگير آلودگى با

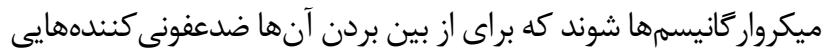

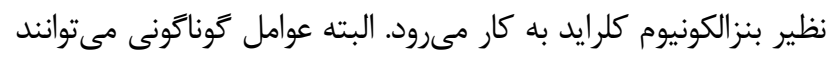

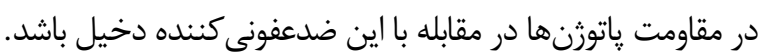
و ممكاران (YFourai

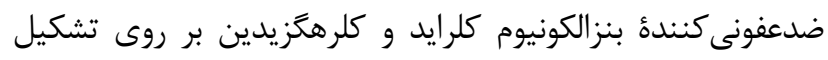

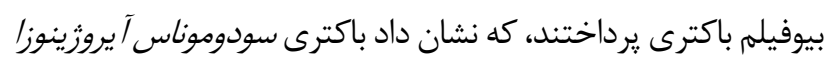
مقاومت بيشترى نسبت به ضدعفونى كننده بنزالكونيوم كلرايد دارد.

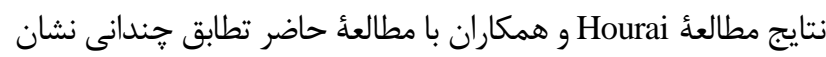

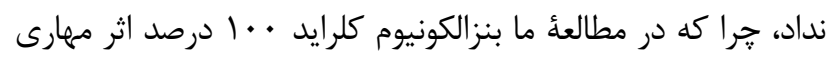

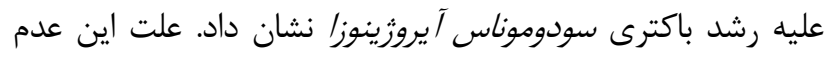

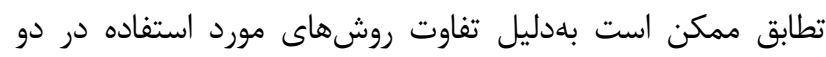

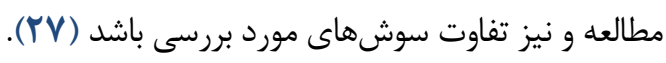
Carson

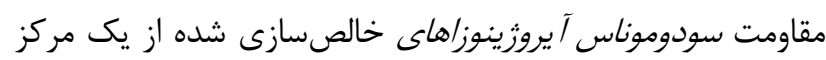

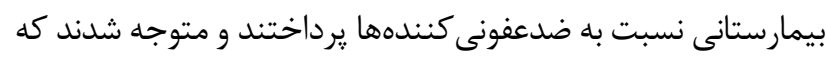

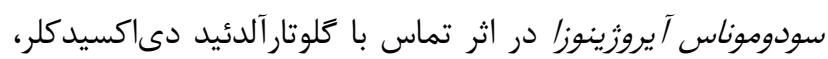

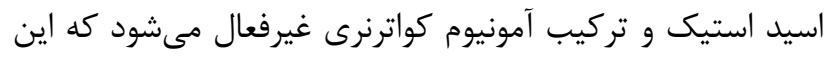
غيرفعال شدن وابسته به عواملى نظير مرحله رشد در زمان تماس باس

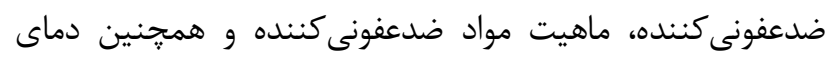

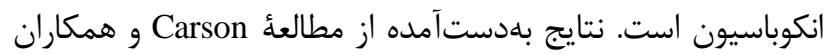
در رابطه با تأثير تركيب آمونيوم كواترنرى بر سودوموناس آ يروثينوزا

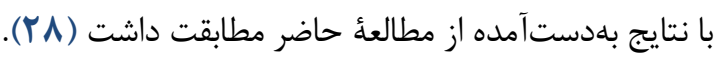
و و ممكاران ( Olasehinde

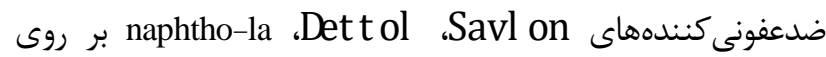
باكترىهاى سودوموناس آيروزينوزا، سالمونلا تيفى و و يروتئوس

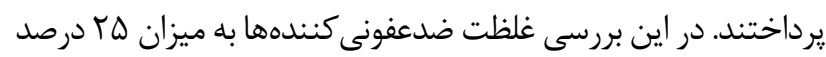
افزايش داده شد و نتايج نشان داد كه تمامى ضدعفونى كنندهها در رقتهاى اوليه نسبت به ميكروار كانيسمها قدرت مهارى ضعيفترى دان

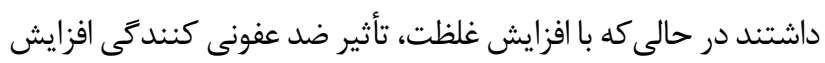

در اين يزوهش مشخص كردن اين كه كدام يك از ضدعفونى كنندها قوى ترين ضدعفونى كننده است بسيار دشوار

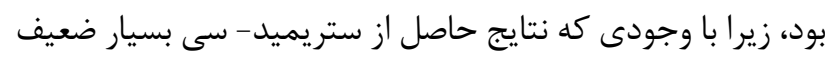

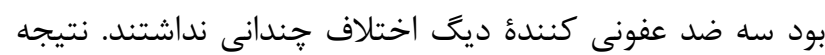

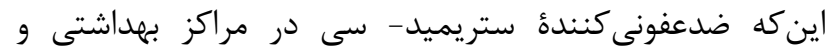

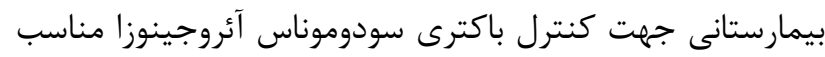

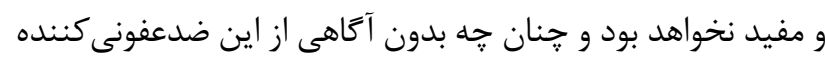

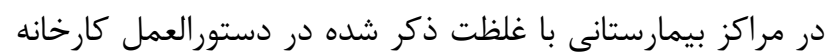
توليدى استفاده شود نه تنها توانايى مهار رشد باكترى را ندارد بلكه

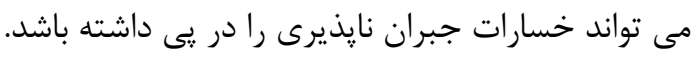
همسو با يزوهش حاضر مطالعات ديخرى انجام گرفته از جمله:

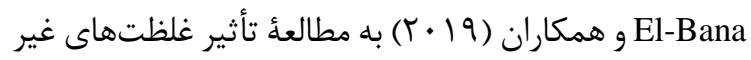

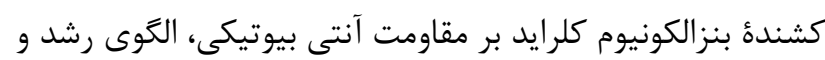

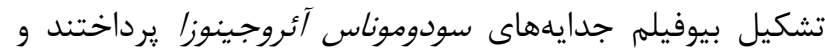
نتايج نشان داد در اين غلظتها افزايش تشكيل بيوفيلم و مقاومت بدائ

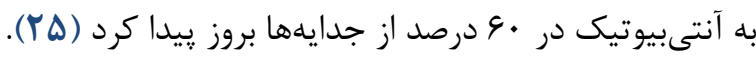
Montagna ضد باكتريايى بيمارستانى (تركيبات فنوليك، تركيبات آمونيوم

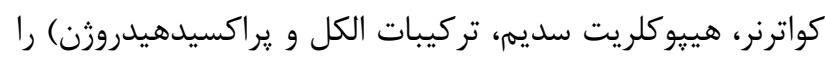

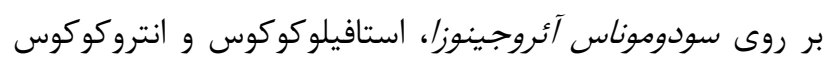
بررسى كردند. نتايج نشان داد كه يراكسيد هيدروزن تنها

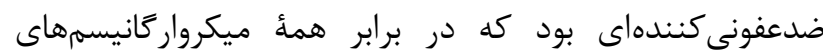

آزمايش شده در همؤ غلظتها اثر مهارى نشان مى برداد (1). و و همكاران (19ijaya

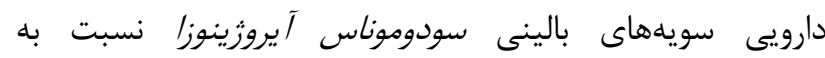

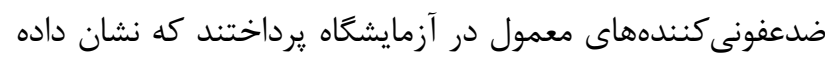

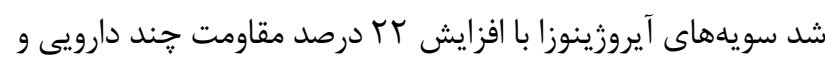

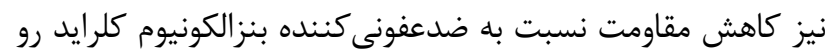

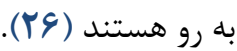




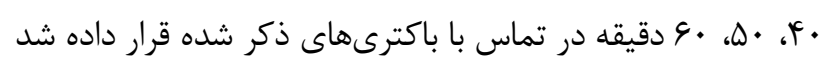
و متوجه شدند كه Virkon S قادر است آنتىرن سطحى هياتيت را نابود كند. همجنين دريافتند كه Virkon S براى نابودى اسيور نيز

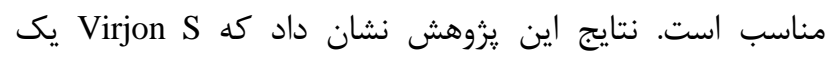

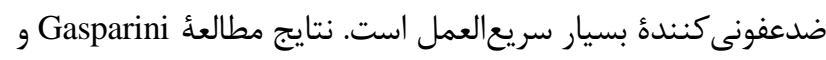
همكاران در مورد اثركذارى وايكوسيانس بر سودوموناس آيروزينوزا با نتايج مطالعئ حاضر در تطابق كامل است (اس).

$$
\text { سياسگزارى }
$$

يزوهش حاضر بركرفته از پاياننامه دانشجويى كارشناسى ارشد باكترىشناسى دانشعاه شهركرد مىباشد. نويسند أن مقاله

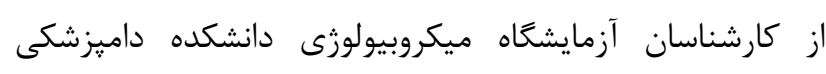
دانشخاه شهر كرد سياسگزارى مى كنيند.

$$
\text { تعارض در منافع }
$$

اين مقاله يروهشى مستقل است كه بدون حمايت مالى إنى سازمانى انجام شده است. در انجام مطالعهُ حاضر، نويسندكان هيجزَنه تضاد منافعى نداشتهاند.

\section{Referance}

1. Montagna MT, Triggiano F, Barbuti G, Bartolomeo N, De Giglio O, Diella G, Lopuzzo M, Rutigliano S, Serio G, Caggiano G. Study on the In Vitro Activity of Five Disinfectants against Nosocomial Bacteria. Int J Environment Res Public Health. 2019 Jan;16(11):1895. [DOI:10.3390/ijerph16111895] [PMID] [PMCID]

2. West AM, Teska PJ, Lineback CB, Oliver HF. Strain, disinfectant, concentration, and contact time quantitatively impact disinfectant efficacy. Antimicrob Resist Infect Control. 2018 Dec;7(1):49. [DOI:10.1186/s13756-018-0340-2] [PMID] [PMCID]

3. Xia J, Gao J, Tang W. Nosocomial infection and its molecular mechanisms of antibiotic resistance. Biosci Trend. 2016;10(1):14-21. [DOI:10.5582/bst.2016.01020] [PMID]

4. Watanabe S, Ohnishi T, Yuasa A, Kiyota H, Iwata S, Kaku M, Watanabe A, Sato J, Hanaki H, Manabe M, Suzuki T. The first nationwide surveillance of antibacterial susceptibility patterns of pathogens isolated from skin and soft-tissue infections in dermatology departments in Japan. J Infect Chemo. 2017 Aug 1;23(8):503-11. [DOI:10.1016/j.jiac.2017.05.006] [PMID]

5. Yamagishi Y, Hagihara M, Kato H, Hirai J, Nishiyama N, Koizumi Y, Sakanashi D, Suematsu H, Nakai H, Mikamo $H$. In vitro and in vivo Pharmacodynamics of Colistin and Aztreonam Alone and in Combination against Multidrug-
ييدا كرد (૧ (ץ). يافتههاى اين يزوهش در مورد ضعيف بودن اثر

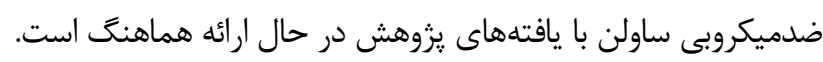
و و همكاران (Nassan

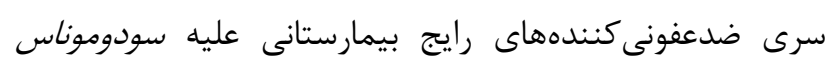
آيروزينوزا جدا شده از عفونتهاى بيماران يرداختند. سويههاى

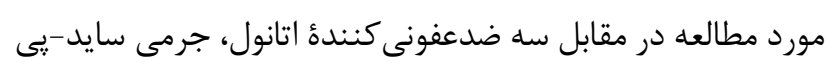

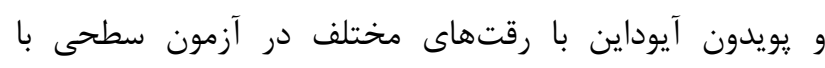

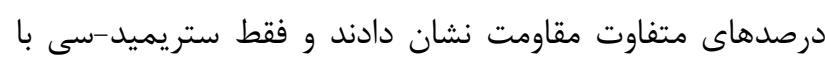

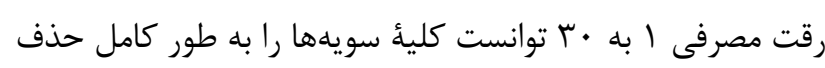

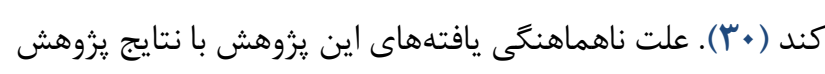

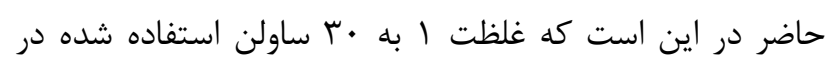
مطالعهُ لطفى يور و همكاران بسيار بيشتر از غلظت توصيه شده توسط كارخانه توليدى در مطالعه حاضر است.

Virkon و همكاران (1990 (19) به موضوع ميزان تأثير Gasparini

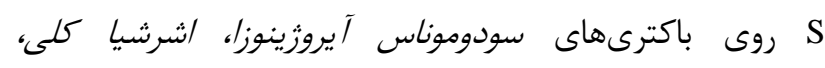

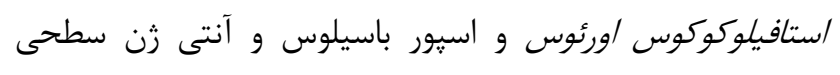

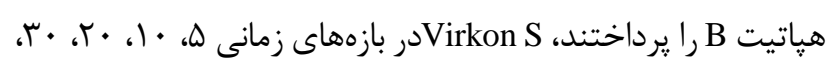

Resistant Pseudomonas aeruginosa. Chemotherapy. 2017;62(2):105-10. [DOI:10.1159/000449367] [PMID]

6. Scano A, Serafi G, Fais S, Bomboi S, Peri M, Ibba A, Girometta G, Orrù G, Rossi P, Sanna P, Coghe F. Antimicrobial susceptibility pattern to disinfectants in Pseudomonas aeruginosa strains isolated from dairy sheep breeds in Sardinia. Large Animal Rev. 2019 Apr 18;25(1):11-5.

7. Stefani S, Campana S, Cariani L, Carnovale V, Colombo C, Lleo MM, Iula VD, Minicucci L, Morelli P, Pizzamiglio G, Taccetti G. Relevance of multidrugresistant Pseudomonas aeruginosa infections in cystic fibrosis. Int J Medic Microbiol. 2017 Sep 1;307(6):35362. [DOI:10.1016/j.ijmm.2017.07.004] [PMID]

8. Ferris RA, McCue PM, Borlee GI, Glapa KE, Martin KH, Mangalea MR, Hennet ML, Wolfe LM, Broeckling CD, Borlee BR. Model of chronic equine endometritis involving a Pseudomonas aeruginosa biofilm. Infect Immun. 2017 Dec 1;85(12):e00332-17. [DOI:10.1128/IAI.00332-17] [PMID] [PMCID]

9. Argyraki A, Markvart M, Nielsen A, Bjarnsholt $\mathrm{T}$, Bjørndal L, Petersen PM. Comparison of UVB and UVC irradiation disinfection efficacies on Pseudomonas Aeruginosa (P. aeruginosa) biofilm. InBiophotonics: Photon Solutions Better Health Care V 2016 Apr 27 (Vol. 9887, p. 988730). International Society for Optics and Photonics. [DOI:10.1117/12.2225597] 
10. Lineback CB, Nkemngong CA, Wu ST, Li X, Teska PJ, Oliver HF. Hydrogen peroxide and sodium hypochlorite disinfectants are more effective against Staphylococcus aureus and Pseudomonas aeruginosa biofilms than quaternary ammonium compounds. Antimicrobial Resistance \& Infection Control. 2018 Dec 1;7(1):154. [DOI:10.1186/s13756-018-0447-5] [PMID] [PMCID]

11. ECDC2018:https://www.thelancet.com/journals/laninf/arti cle/PIIS1473-3099 (18)30605-4/sec1 (accessed on 23 January 2019).

12. Rahimzadeh Torabi L, Doudi M, Golshani Z. The frequency of blaIMP and blaVIM carbapenemase genes in clinical Isolates of pseudomonas aeruginosa in Isfahan medical centers. Medi J Mashhad University Medic Sci. 2016;59(3):139-47.

13. Rokoei F, Rezaei S, Karbasian M, Sadaee N, Rastegar Lari A. Comparison of the antibacterial activity of Handsept and Decosept . Iran J Med Microbiol. 2008; 1 (4) :51-57

14. Subedi D, Vijay AK, Willcox M. Study of Disinfectant Resistance Genes in Ocular Isolates of Pseudomonas aeruginosa. Antibiotics. 2018 Dec;7(4):88. [DOI:10.3390/antibiotics7040088] [PMID] [PMCID]

15. Espinal MA, Laszlo A, Simonsen L, Boulahbal F, Kim SJ, Reniero A, Hoffner S, Rieder HL, Binkin N, Dye C, Williams R. Global trends in resistance to antituberculosis drugs. New England Journal of Medicine. 2001 Apr 26;344(17):1294-303. [DOI:10.1056/NEJM200104263441706] [PMID]

16. Abdollahzadeh Fatemeh, Hakami Vala Mojdeh, Bagheri Bajestani Fatemeh, Bahar Mohammad Reza. Evaluation of ESBL Extended Beta Lactamase Production from Pseudomonas aeruginosa strains isolated from burn patients admitted in Shahid Motahari Hospital. Tehran Iran. 2011; 47-42: 1.

17. Damin Teb Rooz. Intra Hyvarocare.2019. Availablc at: www.daminteb.com

18. Gasparini R, Pozzi T, Magnelli R, Fatighenti D, Giotti E, Poliseno G, Pratelli M, Severini R, Bonanni P, De Feo L. Evaluation of in vitro efficacy of the disinfectant Virkon. Europ J Epidemiol. 1995 Apr 1;11(2):193-7. [DOI:10.1007/BF01719487] [PMID]

19. Furi L, Ciusa ML, Knight D, Di Lorenzo V, Tocci N, Cirasola D, Aragones L, Coelho JR, Freitas AT, Marchi E, Moce L. Evaluation of reduced susceptibility to quaternary ammonium compounds and bisbiguanides in clinical isolates and laboratory-generated mutants of Staphylococcus aureus. Antimicrob Agents Chemo. 2013 Aug 1;57(8):3488-97. [DOI:10.1128/AAC.00498-13] [PMID] [PMCID]

20. Alzubeidi YS, Udompijitkul P, Talukdar PK, Sarker MR. Inactivation of Clostridium perfringens spores adhered onto stainless steel surface by agents used in a clean-inplace procedure. Int J Food Microbiol. 2018 Jul 20;277:26-33. [DOI:10.1016/j.ijfoodmicro.2018.04.016] [PMID]

21. Webb HE, Brichta-Harhay DM, Brashears MM, Nightingale KK, Arthur TM, Bosilevac JM, Kalchayanand N, Schmidt JW, Wang R, Granier SA,
Brown TR. Salmonella in peripheral lymph nodes of healthy cattle at slaughter. Frontiers Microbiol. 2017 Nov 9;8:2214. [DOI:10.3389/fmicb.2017.02214] [PMID] [PMCID]

22. Uppal S, Bazzi A, Reynolds RK, Harris J, Pearlman MD, Campbell DA, Morgan DM. Chlorhexidine-alcohol compared with povidone-iodine for preoperative topical antisepsis for abdominal hysterectomy. Obstet Gynecol. 2017 Aug 1;130(2):319-27. [DOI:10.1097/AOG.0000000000002130] [PMID]

23. Koehler DA, Strevett KA, Papelis C, Kibbey TC. The impact of antibacterial handsoap constituents on the dynamics of triclosan dissolution from dry sand. Chemosphere. $2017 \quad$ Nov 1;186:251-6. [DOI:10.1016/j.chemosphere.2017.07.142] [PMID]

24. Olasehinde GI, Akinyanju JA, Ajayi AA. Comparative Antimicrobial Activity of Commercial Disinfectants with Naphtolics. Res J Microbiol. 2008;3(4):262-8. [DOI:10.3923/jm.2008.262.268]

25. El-Banna T, El-Aziz AA, Sonbol F, El-Ekhnawy E. Adaptation of Pseudomonas aeruginosa clinical isolates to benzalkonium chloride retards its growth and enhances biofilm production. Molecular biology reports. 2019 Jun 1;46(3):3437-43. [DOI:10.1007/s11033-019-04806-7] [PMID]

26. Vijaya k, Aboody MS, Alfanaisan MK. Sandle T. In vitro susceptibility of multidrug resistant pseudomonas aeruginosa clinical isolates to common biocides. International Journal of Pharmaceutical Sci Res. 2016; 7(1): 110-16.

27. Houari A, Di Martino P. Effect of chlorhexidine and benzalkonium chloride on bacterial biofilm formation. Let Appl Microbiol. 2007 Dec;45(6):652-6. [DOI:10.1111/i.1472-765X.2007.02249.x] [PMID]

28. Olasehinde GI, Akinyanju JA, Ajayi AA. Comparative Antimicrobial Activity of Commercial Disinfectants with Naphtolics. Res J Microbiol. 2008;3(4):262-8. [DOI:10.3923/jm.2008.262.268]

29. Carson LA, Favero MS, Bond WW, Petersen NJ. Factors affecting comparative resistance of naturally occurring and subcultured Pseudomonas aeruginosa to disinfectants. Appl. Environ. Microbiol. 1972 May 1;23(5):863-9. [DOI:10.1128/AEM.23.5.863-869.1972] [PMID] [PMCID]

30. Hassan M, Kjos M, Nes IF, Diep DB, Lotfipour F. Natural antimicrobial peptides from bacteria: characteristics and potential applications to fight against antibiotic resistance. J Appl Microbiol. 2012 Oct;113(4):723-36. et al. [DOI:10.1111/j.1365-2672.2012.05338.x] [PMID]

31. Gasparini R, Pozzi T, Magnelli R, Fatighenti D, Giotti E, Poliseno G, Pratelli M, Severini R, Bonanni P, De Feo L. Evaluation of in vitro efficacy of the disinfectant Virkon. Europ J Epidemiol. 1995 Apr 1;11(2):193-7. [DOI:10.1007/BF01719487] [PMID] 